\title{
The Latvian direct democracy tools in a comparative European context
}

OÑATI SOCIO-LEGAL SERIES VOLUME 10, ISSUE 4 (2020), 744-788: INVESTIGATIONS INVESTIGACIONES - IKERLANAK

DOI LINK: HTTPS:/DOI.ORG/10.35295/OSLS.IISL/0000-0000-0000-1075

RECEIVED 03 APRIL 2019, ACCEPTED 03 SEPTEMBER 2019

\section{FABIO RATTO TRABUCCO* (D)}

\section{Abstract}

This article analyses and compares the legal tools of direct democracy in Latvia and other European countries. Based on comparison, the author draws concludes the shortcomings of the legal framework of direct democracy in the Constitution of the Republic of Latvia. The author analyses functioning of the direct democracy tools in Latvian practice and compares them with similar tools in other European countries, expressing his criticism towards Latvian legislation on the referendum and people's initiative, finding that some mechanisms included in the Constitution are oldfashioned and ineffective. The article identifies actual shortcomings of the legal framework of the referendum and popular initiative both at the level of the Constitution and that of the law and makes suggestions for improvements of the mechanisms of direct democracy, particularly taking into account the experience of the other Baltic countries.

\section{Key words}

Latvia; national referendum; people's initiative; parliamentary dissolution; recall referendum

\section{Resumen}

Este artículo analiza y compara las herramientas legales de la democracia directa en Letonia y en otros países europeos. Sobre la base de la comparación, el autor extrae conclusiones sobre las deficiencias del marco legal de la democracia directa letona. El autor analiza la legislación y la práctica letona sobre el referéndum y la iniciativa popular comparándola con las de otros países europeos, incluido el referéndum sobre la disolución del Parlamento, expresando críticas de que una serie de

I wish to thank Profs. Annija Kārkliņa and Anita Rodina from the University of Latvia in Riga for the excellent and helpful research assistance.

* Adjunct Professor in Comparative Public Law, University of Cassino, University Avenue, Cassino, Italy. Email address: fabio.rattotrabucco@iuav.it Researcher ID: B-5831-2018. 
institutos parecen anticuados e ineficaces. El artículo identifica las deficiencias actuales del marco legal del referéndum y de la iniciativa popular tanto a nivel constitucional como legislativo e indica sugerencias para mejorar los mecanismos de la democracia directa letona, particularmente teniendo en cuenta la experiencia de otros países bálticos.

\section{Palabras clave}

Letonia; referéndum nacional; iniciativa popular; disolución parlamentaria; referéndum revocatorio 


\section{Table of contents}

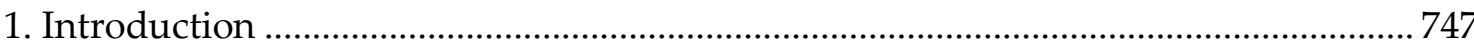

2. The range of opportunities for direct democracy in Latvia ....................................... 748

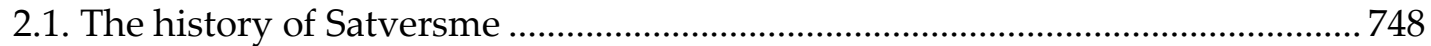

2.2. The referendum provisions in Satversme and legislation .................................. 750

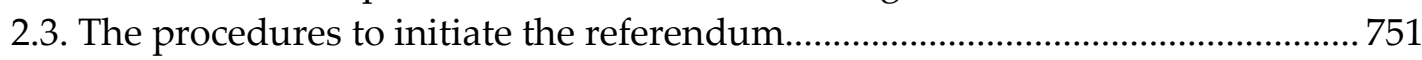

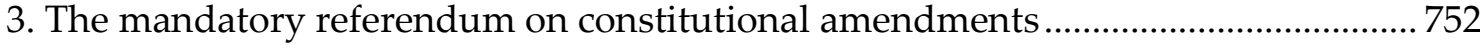

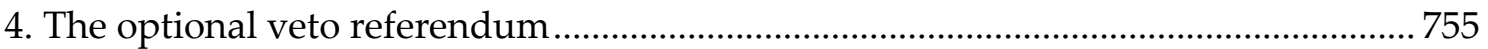

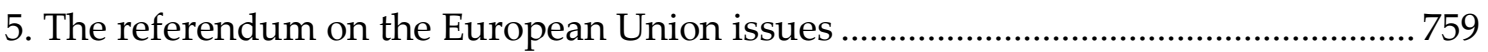

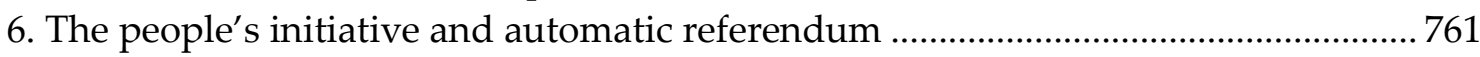

7. The referendum on the dissolution and recalling of the Parliament ........................... 767

7.1. The parliamentary dissolution referendum in a comparative

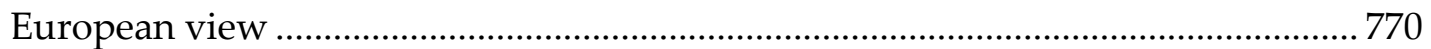

8. The set of issues on the local and consultative referendums

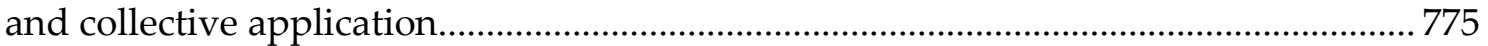

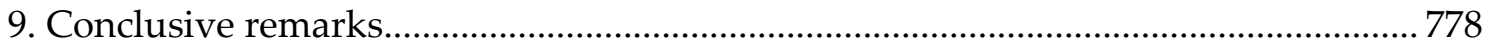

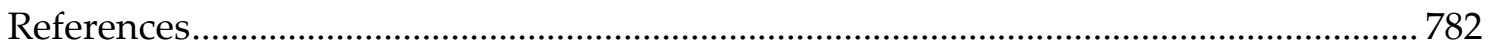

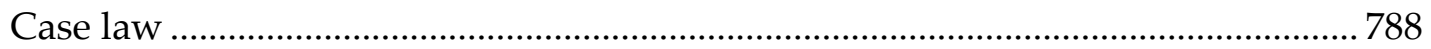

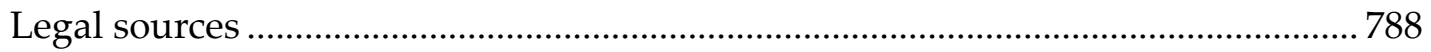




\section{Introduction}

Worldwide direct democracy is characterized by the fact that the people are an organ of the state, that in addition to the classical electoral competences, exercises specific powers in constitutional, conventional, legislative or administrative matters. It is dependent or "domesticated" when the exercise of these powers depends on the intervention or the will of another state body, the Parliament or the Head of State. It is independent or "real" when the time and the issue on which the people intervene depend not on the will of the latter, or on an objective criterion on which other organs of the state have no influence. So defined, direct democracy does not oppose but completes representative democracy (Auer 1995).

Direct democracy has its roots as far back as in ancient Athens and Rome (Held 2006) but nowadays, the direct democracy tools are embodied in almost all Constitutions of the world and particularly, for the field of this article, in the European countries. Although direct democracy can be put into practice in a large variety of forms, in general, there can be observed certain tendencies in the period of modern times: issues of national importance are submitted to the voters for decision-making in an optional referendum which is initiated by the governing bodies; it is the case of a further development of popular initiative (Suksi 1993, Altman 2014, 2019, Qvortrup 2014, 2017, Ruth-Lovell et al. 2017, García et al. 2018, Morel and Qvortrup 2018).

The core concept of democracy is implementing the will of the majority. This is closely related to the principle of national sovereignty. Historically, direct democracy has developed first, which means that the people (voters enjoying full rights to vote) take a political decision or pass a legislative act directly and immediately; however, today the main form of democracy is a representative one. Nowadays, direct democracy should not be considered as opposed to the representative one, as the latter cannot be replaced nor become the main form of decision-making on issues of national importance; it is an additional mechanism in between elections (Gallagher and Uleri 1996, 2, Taube 2001, 200).

The referendum is a mechanism designed for choosing an issue, a decision or a law, considered or adopted by a governing body, to the popular vote. The purpose of a referendum is to decide an issue which is considered by a governing body or to amend a decision which has already been made by a same body. The popular initiative is a request made by a certain number of voters to an authority to adopt, amend or repeal a law or to take a certain action. The purpose of a people's initiative is to point to an issue which may require the adoption of a law or taking another action by a governing body, thus, a popular initiative indicates the inactivity of a same body in a given area.

The referendum device knows neither limits nor any kind of boundary as regards its implementation. Etymologically, it originated in the Swiss Confederation; representatives of each federal body in the Federal Diet used to be sent ad referendum to each respective community, in compliance with the popular mandate they were in charge with, every time they did not receive instructions on given issues being on the agenda of the Federal Diet.

The legislative referendum is a result of the older French constitutionalism since its origins have to be traced back to the Constitution of 1793. Although it was never 
implemented, back then, the legislative referendum was conceived not only for the propositional stage but also for the confirmatory one during the introduction of a new law. However, such a referendum was implemented in its best in Switzerland thanks to the reduced dimensions of the country. Indeed, direct democracy is considered to be the bedrock of the atypical governmental form existing in Switzerland, which omits to express confidence in the executive, as well as in the person of the Head of State alone. That being said, it should be also pointed out that the executive enjoys a four-year-long mandate, the so-called Directorate, whereas the Parliament convenes only four times per year, precisely as a direct consequence of the massive exploitation of direct democracy.

The constitutional referendum is instead a result of the American constitutionalism; its roots can be found in the very first consultation it was ever submitted concerning different Constitutions, in this case, the Constitutions of the thirteen US member states.

Moreover, in countries like Italy and France, it is usually distinguished between referendum and plebiscite (Denquin 1976). Leaving aside the etymological difference between the two terms just mentioned, it is difficult to find a definite, scientific criterion that could justify a similar distinction (Hamon 2012).

Nowadays, referendums exist in almost all European countries, while popular initiatives exist for constitutional and primary legislative provisions only in twentytwo states ${ }^{1}$ on fifty in total, and in Switzerland just for constitutional provisions. However, as it is well known, Confoederatio Helvetica has the longest, most detailed and comprehensive experience of citizens' law-making in the world (Fossedal 2002).

The aim and tasks of this research would like focused on Latvia referendum's case by a legal methodology. Particularly, in the paper, such concepts as "mandatory referendum", "optional referendum", "optional veto referendum", "automatic referendum", "optional active referendum", "consultative referendum", and "recall referendum", are used when provisions in the Latvian Constitution are analysed and compared. As they are not called like this in the Charter the use of such wording or typology needs explanation also in comparison with the other European countries' experiences.

\section{The range of opportunities for direct democracy in Latvia}

\subsection{The history of Satversme}

The Latvian Constitution (Satversme) was drawn up in 1920 by the Constitutional Assembly of Latvia (Satversmes sapulce), composed of 150 members elected by universal suffrage $^{2}$. The rough draft was influenced by the German Weimar Constitution (Weimarer Verfassung) of August 11, 1919, and the Swiss one of 29 May 1874, where it was widely used the direct democracy tools (Ciammariconi and Di Gregorio 2005). By annexing Latvia to SSSR, art. 1 of the Satversme on the national independence was

\footnotetext{
${ }^{1}$ In Europe the popular initiative exists for constitutional and primary legislative provisions in Albania, Andorra, Austria, Azerbaijan, Belarus, Bulgaria, Finland, Georgia, Italy, Lichtenstein, Kosovo, Latvia, Lithuania, Macedonia, Montenegro, Netherlands, Poland, Portugal, Romania, Serbia, Slovenia, and Spain. 2 See https://www.constituteproject.org/constitution/Latvia 2007.pdf [accessed 1 June 2020]. In terms of the history of elaboration of Latvian Constitution see Bleiere et al. 2006.
} 
totally infringed; ${ }^{3}$ in 1940, a Constitution of the Latvian SSR based on the Soviet one of 1936 was ratified and in 1978, it was replaced with a new version, once again inspired by the Soviet one and eventually adopted in the previous year.

On 4 May 1990, the Latvian Supreme Soviet declared the re-establishment of independence after a transitional period and re-enacted arts. 1, 2, 3 and 6, Const. 1922, on national sovereignty ${ }^{4}$ and people's election of Saeima. ${ }^{5}$ Pending the independence process for the Soviet/Russian resistance the remaining part of the Charter was suspended until it was revised to adapt it to the new reality, then Constitution was fully enforced on July 6, 1993, by the V Saeima (after the four assemblies elected between 1922 and 1931), ${ }^{6}$ the first elected after the restoration of independence, according to art. 14 of the law on the Organization of the Supreme Council of the Republic of Latvia.

Therefore, on 12 February 1991, it opted for a popular independence vote which took place on 3 March 1991; in that way, the first referendum, in which all residents before 1940 and her families at the voting age of 18 years could vote, was held in post-Soviet Latvia, achieving moreover a high turnout (Lieven 1993). ${ }^{7}$

However, the referendum tools already appear in the Latvian Constitution of 1922, at the time of the first independence of the country. The Constitution provided a classical parliamentary system of government and it was possible to turn to the people's vote if the Head of State considered appropriate to dissolve the unicameral Parliament in advance. The President of the Republic could submit the request to the people and if the majority of the voters expressed their favour, Parliament was dissolved as a result and new elections would have to take place within two months (art. 48, Const.). If the majority of the voters expressed against the presidential proposal, the Head of State was consequently removed from the office and the Parliament would elect an ad interim substitute, until the expiry of the President's mandate (art. 50, Const.). Similarly at art. 43, Weimar Const., even, in this case, the referendum took the shape of a vote of mistrust against one of the two organs (President or Parliament), whose policy-making role was no longer approved by voters (Baldin 2012,5). Thus, we can see that letting the whole people decide about the fate of the acting President as well as about the duration of the sitting Parliament (Haungs 1968, 30) has been an essential part of the Latvian Constitution as well as the Weimar one (Shen 2009).

\footnotetext{
${ }^{3}$ Art. 1, Const. 1922, declared: "Latvia is an independent democratic republic".

${ }^{4}$ Arts. 2 and 3, Const. 1922, declared respectively: "The sovereign power of the State of Latvia is vested in the people of Latvia" and "The territory of the State of Latvia, within the borders established by international agreements, consists of Vidzeme, Latgale, Kurzeme, and Zemgale".

${ }^{5}$ Art. 6, Const. 1922, declared: "The Saeima shall be elected in general, equal and direct elections, and by secret ballot based on proportional representation".

${ }^{6}$ In pre-war Latvia, Saeima was elected for three-year terms. I Saeima met from November 7, 1922, until November 2, 1925. II Saeima from November 3, 1925, until November 5, 1928. III Saeima from 6 November 1928, until 2 November 1931. IV Saeima met from 3 November 1931, until 15 May 1934, for the coup d'état by the Prime Minister Ulmanis.

7 The question of the referendum on Latvian independence was worded as follows: "Are you in favour of a democratic and independent Republic of Latvia?", and it was approved by $74.90 \%$ votes with a turnout of $87.56 \%$. On the "democratic efficiency" of such a vague formula of the issue at stake.
} 
This is a peculiar recall referendum case that recurred in the Icelandic Constitution of 1944 as well, which provides for a revocation referendum to be brought into action once reached the resolution of three-quarters of the members of the assembly, leading to the suspension of the President and new elections in two months (Baldin 2012, 6). If the request for revocation is not approved by popular vote, the Parliament of the island (Alpingi) is dissolved and new elections are launched (art. 11, para. 3, Const.) (Thorarensen 2015).

Surely Latvia is one of the few countries in Europe in which the citizens have a full range of initiative and referendum rights which enable them to launch initiatives to amend the Constitution, create a new law, or veto a decision taken by Parliament. The direct democracy tools (both referendums and popular initiatives) includes the nationwide referendum and the nationwide people's initiative; the regional (local) referendum and the regional (local) popular initiative.

\subsection{The referendum provisions in Satversme and legislation}

Generally speaking, the current Constitution of the Republic of Latvia specifies seven types of national referendums (arts. 14 and 48, paras. 3 and 4 of 68, 72, 77, 78 and 79, Const.) and the popular initiative (art. 78, Const.) (Balodis et al. 2013, Somer 2014, 6085).

If the Saeima amends arts. 1, 2, 3, 4, 6 and 77, Const., such amendments, in order to come into force as law, shall be submitted to a national referendum and are adopted if at least half of the electorate has voted in favour (mandatory referendum on constitutional amendments by art. 77 and 79, Const.).

The President of Latvia can suspend the proclamation of a law for two months, and in this period, a petition initiated by not less than one-tenth of the electorate can cause the suspended law to be submitted to a national referendum. A law is deemed repealed by national referendum if the number of voters is at least half of the number of electors as participated in the previous Saeima election and if the majority has voted for repeal of the law (optional veto referendum by art. 72, Const.).

The Saeima cannot adopt a draft law or a draft amendment to the Constitution submitted by not less than one-tenth of the electorate without change of their content. In this case, if an amendment to the Constitution submitted to the national referendum will be adopted, at least half of the electorate needs to vote in favour. However, a draft law submitted to the national referendum can be adopted, only if the number of voters is at least half of the number of electors as participated in the previous Saeima election and if the majority has voted in favour of the draft law popular initiative and automatic referendum (people's initiative and automatic referendum by art. 78, Const.).

Supposing that it has to be decided on Latvia's membership in the European Union (EU), then there will be a referendum and the Latvian accession to EU will be adopted if the number of voters is at least half of the number of electors as participated in the previous Saeima election and if the majority has voted in favour of the membership of Latvia in the EU (referendum of EU access by art. 68, para. 3, Const.). 
In this respect, the substantial changes in the terms regarding the membership of Latvia in the EU must be decided, and at least one-half of the members of the Saeima has requested a national referendum on this matter. A draft law or decision regarding substantial changes in the terms regarding such membership submitted for national referendum will be adopted if the number of voters is at least half of the number of electors as participated in the previous Saeima election and if the majority has voted in favour of the draft law or substantial changes in the terms regarding such a membership (referendum of EU issues by art. 68, para. 4, Const.).

The President of Latvia can propose the dissolution of the Saeima: if in the referendum more than half of the votes are cast in favour of dissolution, the Saeima is considered dissolved and new elections are called. If more than half of the votes are cast in the referendum against the dissolution of the Saeima, then the President is deemed removed from office and the Saeima elects a new President to serve for the remaining term of office of the President so removed (referendum on the dissolution of the Parliament by art. 48 , Const.).

Finally, at least one-tenth of the electorate can propose the dissolution of the Saeima. If the majority of voters and at least two-thirds of the number of the voters who participated in the last elections of the Saeima vote in the national referendum regarding the recalling of the Saeima, then the Saeima is recalled. The right to initiate a national referendum regarding recalling of the Saeima may not be exercised one year after the convening of the Saeima and one year before the end of the term of office of the Saeima, during the last six months of the term of office of the President, as well as earlier than six months after the previous national referendum regarding recalling of the Saeima (referendum on recalling of the Parliament by art. 14, Const.).

Both budget and laws concerning loans, taxes, customs duties, railroad tariffs, military conscription, declaration and commencement of the war, peace treaties, declaration of a state of emergency and its termination, mobilization, and demobilization, as well as agreements with other nations, may not be submitted to a national referendum. If the Saeima, by not less than a two-thirds majority vote, determine a law to be urgent, it may not be submitted to a national referendum, either. The reasons for such prohibition have been prescribed in other European constitutions (Italy included) to protect the balance between representative and direct democracy.

\subsection{The procedures to initiate the referendum}

According to the law on National Referendums, Legislative Initiatives and European Citizens' Initiative, ${ }^{8}$ adopted by the Parliament on 31 March 1994, an initiative group must register a draft law or draft amendment to the Constitution of the Republic of Latvia with the Central Election Commission (Centrālā Vēlēšanu Komisija, CVK) before starting collecting signatures. It is not a referendum in itself, but rather an opportunity to come up with an initiative on the issue concerning the above-mentioned parliamentary bodies.

\footnotetext{
8 See https://likumi.lv/ta/en/id/58065-on-national-referendum-legislative-initiative-and-european-citizensinitiative [Accessed 1 June 2020].
} 
An initiative group may be a political party or association of political parties, as well as a registered association of at least ten electors. Collection of signatures may be organized only if the draft law or draft amendments to the Constitution are completely evolved as to their form and contents.

If the draft law or draft amendments to the Constitution is supported by not less than one-tenth of the citizens of Latvia eligible to vote in the previous Saeima elections, it is sent to the President who submits it to the Saeima. The Saeima must consider the draft law or the draft amendment to the Constitution during the session when the draft was submitted.

If the Saeima does not adopt a draft law or a draft amendment to the Constitution without any change as to their content, then they must be submitted to a national referendum.

According to the Referendum law, Latvian citizens eligible to vote are also entitled to initiate a national referendum on the dissolution of the Saeima. Collection of signatures is organized similarly. The signatures of not less than one-tenth of the voters are necessary to organize a national referendum on the dissolution of the Saeima.

According to art. 14, Const., voters may not exercise the right to recall the parliament one year after the convening of the Saeima, one year before the end of the term of office of the Saeima, during the last six months of the term of office of the President, as well as earlier than six months after the previous national referendum regarding recalling of the Saeima.

Lastly, art. 131, paras. 3 and 5, of the Rules of Procedure of the Saeima, ${ }^{9}$ provide that at least 10,000 Latvians who have reached the age of 16 years on the day of filing a submission shall have a right to file a collective submission with the Parliament. The collective submission shall contain a request to the Saeima and a brief justification of the request, as well as including the natural person authorized to represent the signatories of the collective submission, this person's address, and contact information. Each signatory of the collective submission shall legibly indicate his/her name, surname, and ID number. As mentioned below, it shall also be possible to collect signatures electronically by web portal as long as the possibility to identify signatories and protection of personal data is ensured. ${ }^{10}$

\section{The mandatory referendum on constitutional amendments}

The referendum set out in art. 77, Const., is a mandatory referendum which must be held whenever the Parliament amends articles on general provisions of the Latvian Constitution, even if, by Constitutional Court, the Parliament amends the mentioned articles not textually, but in substance: ${ }^{11}$ these articles set out issues of the utmost

\footnotetext{
${ }^{9}$ See https://www.saeima.lv/en/legislation/rules-of-procedure [Accessed 1 June 2020].

10 Currently, the most comfortable way for citizens to do that is through the website https://www.manabalss.lv. Authorization is done through the same system people use to log on to their ebanking systems.

${ }^{11}$ Art. 77, Const., declares: "If the Parliament has amended the first, second, third, fourth, sixth or seventyseventh Article of the Constitution, such amendments, in order to come into force as law, shall be submitted for a national referendum".
} 
importance for the Republic of Latvia, ${ }^{12}$ they establish the basic principles of the political system of the State (Judgment of the Latvian Constitutional Court of 29 November 2007, case no 2007-10-0102). ${ }^{13}$

Art. 77, Const., should be viewed in conjunction with art. 79, Const.; para. 1 of art. 79 declares that an amendment to the Constitution submitted for the national referendum must be deemed adopted if at least half of the electorate has voted in favour. Consequently, art. 79, Const., sets out an extremely high approval quorum. Analysing arts. 77 and 79, Const., in conjunction, it is evident that neither the Constitutional Assembly nor the Parliament had an intention to set up arrangements for amendments of arts. 1, 2, 3, 4, and 6, Const. The meaning and the purpose of these articles have always been and still are to make arts. 1, 2, 3, 4, and 6, Const., practically unchangeable, thus to preclude any change concerning the very basis of the democratic State (Ciammariconi and Di Gregorio 2005, 1410, Roznai 2019).

The Constitutions of Denmark, Ireland, and Switzerland provide for a mandatory referendum on constitutional amendments as well; however, in the mentioned countries, it has been set out much wider, as it applies to the whole text of the Constitution. Nevertheless, the purpose of mandatory referendums on constitutional amendments set out in the Constitutions of Ireland and Switzerland is different from the purpose of arts. 77 and 79, Const. Namely, there is no quorum for the Irish and Swiss mandatory referendum, therefore the purpose of these arrangements is to preclude the Parliament from deciding on issues of the utmost importance on constitutional amendments by itself and to submit decision-making on constitutional amendments to the voters.

As regards Eastern and Central European countries, only four countries provide for a mandatory referendum on constitutional amendments - the Baltic countries (Arts. 163 and 164, Const. Estonia; art. 77, Const. Latvia; art. 148, paras. 1 and 2, Const. Lithuania) and Romania (Art. 147, para. 3, Const. Romania). Estonia and Lithuania, like Latvia, provide for a mandatory referendum only regarding individual articles of the Constitution which set out issues of the utmost national importance as well as on articles which set out arrangements for constitutional amendments. Lithuania, like Latvia, sets out a high quorum for a mandatory referendum - more than half of the electorate must vote in favour of an amendment to certain articles of the Constitution and in favour of an amendment to art. 1, Const. - at least $75 \%$ of the electorate. The purpose of such arrangements, like in Latvia, is to protect the fundamental national values and preclude constitutional amendments to the above-mentioned articles.

The referendum set out in art. 77, Const., has never been held in Latvia; nevertheless, the issue of the necessity to hold a referendum on amendments to arts. 1, 2, 3, 4, 6 or 77,

\footnotetext{
12 The first article of the Constitution states that: "Latvia is an independent democratic republic"; the second article states that: "The sovereign power of the State of Latvia is vested in the people of Latvia"; the third article states that: "The territory of the State of Latvia, within the borders established by international agreements, consists of Vidzeme, Latgale, Kurzeme, and Zemgale"; the fourth article states that: "The Latvian language is the official language in the Republic of Latvia. The national flag of Latvia shall be red with a band of white"; the sixth article states that: "The Parliament shall be elected in general, equal and direct elections, and by secret ballot based on proportional representation".

${ }^{13}$ The Latvian Constitutional Court cases are available from https://www.satv.tiesa.gov.lv/en/cases/.
} 
Const., has been examined in essence. Before Latvia joined the EU, an extensive discussion took place whether Latvian participation in the EU would impact on the concept of independence embodied in the first article of the Constitution and on the concept of sovereignty set out in the second article of the Constitution and whether a referendum as set out in art. 77, Const., had to be held or not. The Working Group established by the Prime Minister as well as by the majority of legal experts reckoned that Latvia would not lose its independence and sovereignty by being a member state of the EU, therefore arts. 1, 2, 3, 4, and 6, Const., were not to amend to (Endziņš 2000, Habracevica 2001, Albi 2005).

The question whether a mandatory referendum had to be held or not arose also as regards the conclusion of the agreement between the Republic of Latvia and the Russian Federation on the Latvian-Russian state border and as regards Latvia's entering the Treaty of Lisbon, amending the Treaty on EU and the Treaty representing the bedrock of the European Community (hereinafter, Treaty of Lisbon). In both cases, referendums were not held.

The Constitutional Court recognized that the conclusion of the agreement between both countries on the Latvian-Russian state border did not infringe art. 3, Const., in adherence to the principle of State continuity already incorporated in the Declaration of Independence of 1990: the Declaration renewed the main article of Satversme and established a transitional period until full recovery of independence. The Constitutional Court claimed that Soviet occupation had been illegal and that Latvia had never been part of the USSR de jure as generally recognized by the international community. ${ }^{14}$

Similarly, the Constitutional Court rejected the provisions of the Treaty of Lisbon infringing the concept of national sovereignty embodied in the art. 2, Const. Indeed, the transfer of several competencies to the EU shall not be regarded as a limitation of sovereignty but rather as its exercise to achieve the objectives set forth in the EU treaties which are not contrary to the values and interests enshrined in the Satversme. Although the Treaty of Lisbon provides for the amendments in decision-making procedure in several sectors by replacing unanimity with qualified majority procedure, possible reduction of the direct influence of Latvia in EU institutions shall be seen in the context with improvements of the Latvian power. Thus, none of the methods of interpretation allows concluding that the para. 4 of art. 68, Const., would place an obligation for the members of the Saeima to initiate a referendum in cases of substantial changes in the terms of the membership of Latvia in the EU. ${ }^{15}$

Hence, in both cases, the Constitutional Court concluded that a referendum had not to be held.

\footnotetext{
14 Judgment of the Latvian Constitutional Court of 29 November 2007, case no 2007-10-0102, paras. 22-27 and 34. See Krūma 2014, 326.

${ }^{15}$ Judgment of the Latvian Constitutional Court of 7 April 2009, case no 2008-35-01, para 17. See Fekete 2018.
} 


\section{The optional veto referendum}

The optional referendum as described in art. 72, Const., is set up exclusively regarding a law adopted by the Parliament. ${ }^{16}$ It can be named as optional veto referendum because the people use their veto right or the right to reject a law adopted by the Parliament.

Art. 72, Const., provides for two cases. Firstly, the President may suspend on his initiative the promulgation of law for two months. In this case, the President may request the opinion of the voters regarding a law adopted by the Parliament. Secondly, art. 72, Const., provides that the President must suspend the promulgation of a law if so requested by not less than one-third of the members of the Parliament. In this case instead, the President's role is passive. The purpose of such arrangements is to protect the opinion of the parliamentary minority. In that way, the minority, which must be composed of at least one-third of the members of the Parliament, is enabled to submit an issue regarding an important law for a referendum.

Moreover, art. 72, Const., provides that a suspended law must be put to a referendum if so requested by not less than one-tenth of the electorate, proving that a specific "twostage procedure" exists in Latvia. In the beginning, signatures of one-tenth of the electorate must be collected - "a request to hold a referendum". If any request arises in two-months, the law must then be promulgated after the expiration of such period. If a requested number of signatures is collected, a referendum can then be held. The purpose of such "two-stage procedure" is to prevent that the President or one-third of the members of the Parliament exercise their right too often and in an uncritical manner. It follows that the right under consideration is connected with the necessity to gain support from the electors; further, the purpose lays also in saving public resources by preventing to hold referendums on issues which do not have support from onetenth of the electorate.

The sixth sentence of art. 72, Const., states that a referendum cannot take place if the Parliament votes once again on the law and not less than three-quarters of all members of the Parliament vote for the adoption of the law. This condition has never been put into practice, without mentioning that it limits the President's action, allowing the Parliament to take priority over him through three-quarters of all votes. In general, it complies with constitutional provisions on presidential powers, which are quite limited. Nevertheless, if at least one-third of the members of the Parliament (33 deputies) demand to the President not to promulgate a law, there is a little possibility that afterward at least three-quarters of the members of the Parliament (75 deputies) would vote in favour of the adoption of the law at issue and against its submission to a referendum.

In Latvia, four referendums have taken place by art. 72, Const., as well as one collection of signatures, which was not followed by a referendum. Only one of them - a

\footnotetext{
${ }^{16}$ An optional veto referendum is set out in art. 72, Const.: "The President has the right to suspend the promulgation of law for a period of two months. The President shall suspend the promulgation of a law if so requested by not less than one-third of the members of the Parliament. This right may be exercised by the President, or by one-third of the members of the Parliament, within ten days from the adoption of the law by the Parliament. The law thus suspended shall be put to a national referendum if so requested by not less than one-tenth of the electorate $(. . .)^{\prime \prime}$.
} 
referendum on the law of 22 June 1998, on Amendments to the law on Citizenship, ${ }^{17}$ which was held at the same time as elections of the VII Saeima, reached the necessary quorum..$^{18}$ The remaining three veto referendums with an insufficient turnout concerned the abolition of the retirement system reform ${ }^{19}$ and the abolition of amendments to the laws on the National Security ${ }^{20}$ and on the State Security Services Authority. ${ }^{21}$

Although nearly all Constitutions of the EU countries include provisions on an optional referendum, a referendum usually has a wider scope, which means that it provides not only for a law or a draft law but also for an issue of national importance, which may be expressed in a free form (Bulgaria, Croatia, Estonia, France, Greece, Lithuania, Poland, Portugal, Romania, Slovakia, Slovenia, etc.). Even more uncommon is an optional veto referendum, that is, a referendum which aims at repealing a law adopted by the Parliament (Austria, Denmark, Ireland, Italy, and Switzerland); however, the nature of optional referendums on a law adopted by the Parliament in Austria, Denmark, Ireland, and Switzerland is not so revocable, as electors do not have to answer to the following question: "Are you in favour of repealing the law [title of the law]?". The repealing (abrogative) referendum in which the electors have to answer to a question regarding whether they are in favour or against repealing the law, exists only in Italy and in two US federal states (Art. 11, Const. Alaska and art. 19, Const. Nevada).

Art. 72, Const., includes an optional repealing referendum which was typical for European countries during the interwar period. Very similar provisions as those of art.

\footnotetext{
${ }_{17}$ Under pressure of the OSCE, the Saeima decided to pass on 22 June 1998, a new law on naturalization dealing with important issues: the "windows" system that allows only a limited number of naturalizations per year, distributed according to year of birth, is abolished; parents non-citizens have the right to ask for Latvian citizenship for those stateless children born after independence (21 August 1991); parents can request citizenship for their children until the age of 15 years, after which a child can make the request on his/her behalf until the age of 17 years; the language proficiency exams are made easier for people older than 65 year. See https://likumi.lv/ta/en/id/57512-citizenship-law [Accessed 1 June 2020].

18 The question of the referendum on the abolition of facilitated naturalization was worded as follows: "Are you in favour of abolishing the amendments of June 22, 1998, to the law on Facilitated Naturalizations?" and was rejected by $53.92 \%$ votes with a turnout of $68.82 \%$, while the participation rate at the parliamentary elections held at the same time was $71.90 \%$.

19 On 5 August 1999, the Parliament approved a new Retirement law, dealing with important issues: increase of the retirement age for women from 57.5 to 62 by 2006; increase of the retirement age for men from 60 to 62 by 2006; working pensioners will lose benefits from 2000 if their wages exceed twice the amount of the pension. The question of the referendum on the abolition of the retirement system reform was worded as follows: "Are you in favour of abolishing the amendments to the Retirement law of August 5,1999 ?", and was approved by $94.63 \%$ votes but with an insufficient turnout of $25.10 \%$.

${ }^{20}$ At end of 2006, considering the emergency clause of art 81, Const., the government enacted two laws on State Security Service, which enabled it to access the data of the intelligence service office, the security police, and the military secret service. The President submitted her first veto which was outvoted by the Saeima but the President submitted a second veto according to art. 72, Const., on both laws of 1 March 2007. See https://likumi.lv/ta/en/id/14011-national-security-law [Accessed 1 June 2020]. The question of the referendum on the abolition of amendments to the law on National State Security was worded as follows: "Are you in favour of the abolition of the amendments to the law on National State Security of March 1, 2007 ?", and was approved by $96.97 \%$ but with an insufficient turnout of $22.59 \%$.

${ }^{21}$ The question of the referendum on the abolition of amendments to the law on State Security Authorities was worded as follows: "Are you in favour of abolition of the amendments to the law on State Security Authorities of March 1, 2007?", and was approved by $96.89 \%$ votes but with an insufficient turnout of $22.47 \%$.
} 
72, Const., were included in art. 73, Const. German Reich of 1919. Nowadays, the vast majority of European countries have abandoned such provisions; they have introduced instead of an optional referendum on issues of national importance which may be submitted by both governing bodies and electors.

Latvia should consider the possibility to introduce modern provisions, such as an optional referendum with the purpose of submitting issues of utmost national importance to the electorate. This kind of alternative referendum could take the place of the optional veto one set out in art. 72, Const., which aims at putting face to face the majority of the Parliament with the electors.

However, if the veto referendum set out in art. 72, Const., is maintained, the following issues should be considered: a possibility to abandon a "two-stage procedure" - the necessity to collect signatures from one-tenth of voters in order to hold a referendum regarding the repealing of a law; a possibility to word a question of the referendum in a manner which is easily and clearly understandable to voters; a possibility to reduce the necessary quorum.

The "two-stage procedure" included in art. 72, Const., is old-fashioned (Taube 2001, 204). It is more likely that the President and one-third of the members of the Parliament may rather be discouraged from exercising their right as set out in art. 72, Const., because of a high quorum required for the referendum to be valid, then because of the requirement to collect signatures from one-tenth of the number of electors. Furthermore, the costs deriving from the collection of signatures from at least onetenth of the number of all electors are comparable to the resources needed for holding a referendum. The requirement to come to a polling station twice contributes to voters' indifference and reduces the possibility to reach a quorum for the referendum.

As regards optional veto referendums, Latvian electors have difficulties in understanding the meaning of the question (Kaufmann and Dane Waters 2004, 80). A voter, while voting "yes", considers it as a vote cast in favour of the content of the law at issue; but voting instead "yes" for the repeal of the law is a vote against the content of the law. Moreover, usually, the referendum question contains only the title of the law, on which basis the voters have to understand the meaning of the law itself. Difficulties in understanding the meaning of the question are typical for optional referendums, as electors are voting on the repeal of the law. A lot of criticism as regards the wording of referendum questions has been expressed towards Italy (ibid., 74), where also a repealing (abrogative) referendum exists. A referendum question should be worded in an easily and unmistakably understandable manner for voters, asking to vote in favour or against the law and not in favour or against its repeal. Thus, to word a referendum question in an understandable manner, appropriate provisions should be set up in the Latvian law on Referendum, Popular Initiative, and European Citizens' Initiative, as the Constitution does not provide for any indication as regards the wording of referendum questions.

Furthermore, as for repealing referendums, there is a high quorum requested in Latvia: at least half of the electors as participated in the previous election of the Parliament must take part in an optional referendum and the majority has to vote for the repeal of the law (art. 74, Const.). In countries where a high quorum is set for a referendum (Italy, Latvia, and Lithuania), relatively many referendums are held, yet they often fail, as a 
necessary quorum is not always reached. At the same time, this current trend indicates that quorum requirements should be abandoned (Code of Good Practice on Referendums, para. III.7).

Repealing referendums particularly suffer from the negative consequences of a relatively high quorum, which have the same effect in Italy as in Latvia. A high quorum, along with a repealing nature of a referendum, creates a situation in which the ruling coalition parties, which are usually interested in non-repeal of a law, persuade the voters not to show up at the polling stations; yet there should not even be any trace of such a practice in a democratic country, as the concept of the direct democracy tools includes the possibility that electors can speak their minds on issues of national importance, including the right to take part in a referendum without unreasonable restrictions, are recognized as human rights. Electors who do not go to polling stations automatically vote against the repeal of a law. However, it has turned out that, usually, the majority of the electors do not take part in a referendum because they are not interested in a particular issue, and not because they are against the repeal of a law. Thus, the outcome of a referendum does not necessarily reflect the true will of the voters. Besides, it is useless to set up a quorum which, in practice, is mostly not reached. In that way, it is not accomplished with the set goal to let the voters decide on issues of national importance, no matter if it entails that public resources have to be invested for this cause.

It should be also taken into account that, in all countries, the number of voters taking part in referendums is usually lower than the number of voters taking part in parliamentary elections (Butler and Ranney 1994, 17, Kobach 2013, 84), therefore it is not reasonable to draw a comparison with the number of citizens who took part in parliamentary elections. The number of voters taking part in referendums is inferior because a referendum is held on one single law or on a particular issue on which the interest of various social groups may differ. The quorum for a referendum should be set up at a level which excludes that a decision is taken by such a little amount of voters that reasonable concerns may arise whether the opinion of the voters regarding a particular law is represented by their vote. Setting up a quorum which in practice is mostly not reached does not meet the goals of modern direct democracy.

Furthermore, the scope of national referendums in Latvia can be much wider than it is provided for by art. 73, Const., which sets out quite broad restrictions regarding the submission of law for a referendum. ${ }^{22}$ This provision may partially be considered as out-of-date, i.e. a prohibition to take a decision in a referendum regarding deep-rooted national traditions (nowadays, it is a matter belonging to the EU scope of competence), railways tariffs (nowadays, the Parliament does not decide on that issue), mobilization, demobilization (many European countries have held such referendums), international agreements. Nowadays, no limits are set on referendum issues in many European countries; besides, in Switzerland referendums on fiscal issues are held as well (Kaufmann et al. 2010, 81).

${ }^{22}$ Art. 73, Const., declares: “Both Budget and laws concerning loans, taxes, customs duties, railroad tariffs, military conscription, declaration and commencement of war, peace treaties, declaration of a state of emergency and its termination, mobilization, and demobilization, as well as agreements with other nations may not be submitted to national referendum". 


\section{The referendum on the European Union issues}

Art. 68, para. 3, Const., declares: "Latvia's membership in the EU shall be decided through a national referendum proposed by the Parliament". In turn, para. 4 of art. 68 provides as follows: "Substantial changes in the terms regarding Latvia's membership in the EU shall be decided by means of a national referendum requested by at least one-half of the members of the Parliament". These provisions were introduced in the Constitution through the law of 8 May 2003. ${ }^{23}$ In 2003, art. 79, Const., was amended as well, providing that a decision regarding Latvia's membership in the EU or substantial changes in the terms regarding such membership submitted for a referendum must be deemed adopted if the number of voters is at least half of the number of electors as participated in the previous election of the Parliament and if the majority has voted in favour of the draft law (Albi 2003, Mikkel and Fridham 2007).

Para. 3 of art. 68, Const., declares for a mandatory referendum. Before Latvia joined the $\mathrm{EU}$, it became apparent that the referendum embodied in the Constitution was not suitable in concrete situations, that is, the Constitution did not provide for the possibility to hold a referendum on abstract matters. In turn, if the President decided, by art. 72 Const., to submit for a referendum on the law on Latvia's membership in the EU, previously already adopted by the Parliament, he would have to collect signatures from at least one-tenth of all electors. That would be necessary to support the referendum proposal, resulting in a referendum on the repeal of the law at issue. A referendum on international agreements (agreements with other nations) was instead expressis verbis prohibited by art. 73, Const. However, before joining EU as the member political need to hold a referendum on the EU membership as well on the constitutional changes regarding the membership in the EU emerged. As a result, the Parliament included two new types of referendums in art. 68, Const.: one on the membership in the EU and the other one on substantial changes in terms regarding Latvia's membership in the EU.

The referendum set out in the Constitution refers only to the membership in the EU (joining and withdrawing); the members of the Parliament did not consider the possibility to go through the same path as the majority of European countries did, that is to include in the Constitution an optional referendum initiated by a governing body, which would enable to hold a referendum on the issue of EU-accession, as well as on other issues.

The purpose of the mandatory referendum on Latvia's membership in the EU is to submit for a referendum one of the issues of the utmost national importance, which is also connected with the question of transferring competencies of governing bodies to the EU. The quorum for a referendum on the membership in the EU, as set out in art. 79, Const., is high; however it is reachable, in practice. ${ }^{24}$

\footnotetext{
${ }^{23}$ See https://ikumi.lv/ta/id/75141-grozijumi-latvijas-republikas-satversme [Accessed 1 June 2020].

${ }^{24}$ The EU accession of Latvia and other nine Central-Eastern European countries was decided during the Copenhagen Summit of 12-13 December 2002. The formal ratification took place on 16 April 2003 in Athens, while the membership occurred on 1 May 2004. On 8 May 2003, the Saeima amended the Constitution by re-enacting art. 68, para. 2 to 4 and altering art. 79. The referendum date was 21 September 2003, and the question of the referendum on the EU adhesion was worded as follows: "Are you in favour
} 
Art. 68, para. 4, Const., includes an optional referendum on substantial changes in terms regarding Latvia's membership in the EU. Taking into account that art. 73, Const., prohibits to submit international agreements (agreements with other nations) for a referendum, therefore it was impossible to hold a referendum on an international agreement which provided substantial changes in the EU structure or its competence or on other important issues. It became than clear that it was necessary to include such referendum in the Constitution, which, incidentally, can be held on European integration issues of the utmost importance, yet it is not possible to submit for a referendum an issue that may produce changes in the EU treaties. A decision, whether changes in terms regarding the membership in the EU are so "substantial" that a referendum is to be held, is in the hands of at least half of the members of the Parliament.

The issue, whether art. 68, Const., sets out a right or an obligation which members of the Parliament are exposed to as regards the submission of a referendum, has been analysed in detail by the Constitutional Court. Submitters of the application in this case pointed out that para. 4 of art. 68, Const., forces the members of the Parliament to submit for a referendum issues concerning substantial changes in terms regarding Latvia's membership in the EU; however, as above mentioned, the Latvian Constitutional Court did not agree with this statement and recognized that a referendum on the Treaty of Lisbon was not going to be held (Judgment of the Latvian Constitutional Court of 7 April 2009, case no 2008-35-01).

Since holding of a referendum on substantial changes in terms regarding the membership of Latvia in the EU must be requested by at least half of the members of the Parliament, a referendum can be required only if there is a broad enough consensus among the political parties.

Although a number of national Constitutions expressis verbis provide for mandatory referendums on joining international organizations if such participation is connected with a transfer of a competence of governing bodies to the international organization (Croatia, Lithuania, and Switzerland), Latvia and the Czech Republic are the only EU countries whose Constitutions provide for a mandatory referendum directly on the membership in the EU. Referendums on joining the EU and in some cases - on substantial changes in the EU - are held also in countries whose Constitutions do not necessarily request it; they are held by terms regarding an optional referendum as in the cases of 2004's France and Netherlands referendums to reject the so-called EU Constitution.

Furthermore, the Central-Eastern EU area with their heterogeneous experimentations, are distinguished by a strong originality in the case of so-called European referendums that were carried out with a suspicious lack of adequate (Mendez et al. 2014). These experiences were interesting also because they have reinforced the tendency for frequent popular consultations on European and international issues that few members of the EU had experienced in the past (Uleri 2003, $274 \mathrm{ff}$.). Consequently, as a result, the related debate should be examined that caused the countries traditionally opposing to

of Latvia's membership in the European Union?". The EU referendum was approved by $67.49 \%$ votes with a turnout of $73.12 \%$. 
the use of referendum tools, to drift into the direction of using the tools more frequently (domino effect).

Particularly, the aim is to investigate the two types of referendums that are more regulated: those concerning international relations and constitutional ones. The object of these consultations is conceptually similar: in the end or in the purpose both affect the fundamental choices of the nation and are considered as the supreme expression of national sovereignty, very emphasized, for example, in the three Baltic countries. Perhaps this trend finds an explanation in the effort by "new" European democracies towards the consolidation of its legitimation in the supranational context? If analysed from this perspective, referendum tools almost end up assuming a role to a certain extent mirroring the one that ordinarily covers into Western Europe? In fact, while in the latter case it is often used to oppose a certain political choice (as in the cases of 2004's France and Netherlands referendums to reject the so-called EU Constitution), in the countries of the former socialist EU states seems, on the contrary, to be the means by which to overcome a foreseeable opposition in the representative body and instead find consensus by addressing directly to the electoral body (Avbelj and Komárek 2012) (i.e. 2003's Poland's EU accession referendum; Jasiewicz 2004). Is this new emphasis on popular consultations justified in the light of the origin of "new" Central-Eastern EU democracies? Has the transition from a long experience of limited sovereignty to new forms of "compression" of sovereignty (albeit to completely different ends), have perhaps seen an attitude of caution about safeguarding the respective legal systems? From this point of view the need to check whether the use of the referendum, next to the prediction of further procedural aggravations or control measures from judicial bodies, testifies to the desire to justify a protection of its fundamental assets, beyond that give the principle of popular sovereignty a finally new and real value.

\section{The people's initiative and automatic referendum}

Latvia's Constitution establishes that voters have the right to legislative initiative (Rodina 2011, 2012, Balodis et al. 2013, 81-85): it is a right that does not exist in all democratic states; at the European scale, such rights are not too widespread either, it is present for constitutional and legislative provisions only in the twenty-two countries (Albania, Andorra, Austria, Azerbaijan, Belarus, Bulgaria, Finland, Georgia, Italy, Lichtenstein, Kosovo, Latvia, Lithuania, Macedonia, Montenegro, Netherlands, Poland, Portugal, Romania, Serbia, Slovenia, and Spain) (Bagni 2017), ${ }^{25}$ and in Switzerland just for constitutional provisions. ${ }^{26}$

According to art. 78, Const., one-tenth of the voters have the right to submit to the Saeima a fully elaborated draft law (it may be a new law or an amendment to an existing law) or draft amendments to the Satversme. However, in order to attain that the

\footnotetext{
25 Albania: 20,000 voters; Andorra: 1/10 voters; Austria: 100,000 voters or 1/6 voters from 3 Länder; Azerbaijan: 40,000 voters; Belarus: 50,000 voters; Bulgaria: voters by law; Finland: 50,000 voters; Georgia: 30,000 voters; Italy: 50,000 voters; Lichtenstein: 1,000 voters; Kosovo: 10,000 voters; Latvia: 1/10 voters; Lithuania: 50,000 voters; Macedonia: 10,000 voters; Montenegro: 6,000 voters; Netherlands: 40,000 voters; Poland: 100,000 voters; Portugal: voters by law; Romania: 100,000 voters; Serbia: 30,000 voters; Slovenia: 5,000 voters; Spain: 500,000 voters.

${ }^{26}$ The initiative for the total or partial revision of the Constitution requires 100,000 voters: arts. 138 and 139, Const. Switzerland.
} 
draft law is submitted to the Saeima, voters must comply with the requirements defined in the law on National Referendums, Initiation of law and European Citizens' Initiative; i.e., they must establish an initiative group that is responsible for the draft law and it must submit a fully elaborated draft law or draft amendments to the Satversme to the Central Election Commission (Centrālā Vēlēšanu Komisija, CVK) for registration (Ciammariconi and Di Gregorio 2005, 1413).

Thus, art. 78, Const., includes two legal tools, that is the article sets out the right to a popular initiative as well as it provides for another type of referendum - a referendum on a draft law which was submitted by the electors, but failed to be adopted by the Parliament without amendments (Kārkliṇa 2017).

The referendum set out in art. 78, Const., can be named an automatic referendum. The referendum mentioned in this article is close to an optional active referendum because it is initiated by electors, even though a referendum is not held at any event, but only if the Parliament does not accept a draft law submitted by the voters.

Detailed procedures on how to implement the will of the voters are set out in the above-mentioned law on National Referendum, Popular Initiative, and European Citizens' Initiative. Before the introduction of the amendments of 8 November 2012, which I will discuss below, the law provided for a people's initiative with a "two-stage procedure", that is, in the first phase, a popular initiative was a private initiative of individuals - "not less than 10,000 citizens of the Republic of Latvia who enjoyed the right to vote, providing their name, surname and personal identity code, had the right to submit a fully elaborated draft law or an amendment to the Constitution to the Central Election Committee". After the signatures of at least 10,000 Latvian citizens who had the right to vote were collected - in the second phase - the State took charge of such signatures, precisely through the institution of the Central Election Commission.

If signatures from not less than one-tenth of the electorate are collected, the President submits a draft law to the Parliament. If the Parliament does not adopt it or adopt it with "amendments in substance", a referendum must be held.

Art. 79, Const., sets up a quorum for a referendum, that is, a draft law must be deemed adopted if the number of voters is at least half of the number of the electors as participated in the last Saeima's elections and if the majority has voted in favour of the draft law. If an amendment to the Constitution is submitted for a referendum, the quorum is even higher, that is, an amendment to the Constitution submitted for a referendum must be deemed adopted if at least half of the electorate has voted in favour (the first sentence of art. 79, Const.).

After the Latvian independence was regained, twelve draft laws initiated by voters were submitted to the Central Election Commission: ${ }^{27}$ in seven cases, the required signatures from one-tenth of the electors were not collected; ${ }^{28}$ in two cases, the

\footnotetext{
27 Until 2014, see the analysis in Somer 2014, 86-103.

${ }^{28}$ Initiatives on: Citizenship law; Amendment to the Satversme on the election of a popular electorate; Amendments to the Satversme on the Education in Latvian; Amendments to the law on Protection of the Rights of the Child; Amendments to the Constitution of the Republic of Latvia; Amendments to the law on National Referendums, Legislative Initiatives and European Citizens' Initiative.
} 
referendums were held, but they did not reach the quorum; ${ }^{29}$ in one case, the Parliament adopted the law without amendments in substance; ${ }^{30}$ in one case, the Central Election Commission found out that the draft law had not been fully elaborated; ${ }^{31}$ and in the last case, the initiative was rejected with high turnout. ${ }^{32}$

In Latvia, there were three examples of automatic referendum experiences on rejected popular initiatives by the Saeima, like the limited increase of public pensions ${ }^{33}$ and Russian as a second official language ${ }^{34}$ that dealt with the recall of the Parliament by people's initiative. ${ }^{35}$

Particularly, only the referendum on the linguistic initiative reached the quorum, yet the absolute majority of the electorate explicitly rejected the initiative. It should be reminded, that there had already been a case of failed popular initiative in 2011 when nationalist movements proposed a later failed initiative for the Latvian monolingualism in public schools. ${ }^{36}$ Indeed, in Latvia, language as a symbol of nationality is more than a statistical matter and it has more political-historical relevance because, during the Russian occupation which lasted more than fifty years, Latvian was systematically suppressed with linguistic assimilation attempts.

In a comparative European view, there are different mechanisms for carrying out people's initiative in various European countries (Austria, Lithuania, Poland, Romania, Slovenia, Spain, and Switzerland), however, a "second stage" following the collection of signatures, fully undertaken by the State, exists in no other European country. Indeed, in case of a Latvian popular initiative, all requested signatures are collected as

\footnotetext{
${ }^{29}$ Collections of signatures for the draft law on Amendments to the Constitution of Latvia about the recall of Saeima and the draft law on Amendments to the law on State Pensions.

${ }^{30}$ Collection of signatures for the draft law on Amendments to the Energy law.

${ }^{31}$ Collection of signatures for the draft law on Amendments to the Citizenship law.

${ }^{32}$ Collection of signatures for amendments to the Constitution of the Republic of Latvia about Russian as the second official language.

33 The proposal had been submitted by the Pensioner's Party and other organizations. The question of the referendum on the limited increase of public pensions was worded as follows: "Are you in favour of the legislative project on amending the law on Popular Pensions?", and it was approved by $96.38 \%$ votes but with an insufficient turnout of $22.90 \%$.

${ }^{34}$ The association Dzimt Valoda (Native Language), whose members are predominantly Russian-speaking Latvians, submitted signatures for a constitutional initiative aiming at revising arts. 4, 18, 21, 101 and 104 , Const., to grant to the Russian language the status of second official national language. The Saeima rejected the proposal and then the Electoral Commission scheduled the voting date. The question of the referendum on Russian as second official language was worded as follows: "Are you in favour of the adoption of the legislative draft titled Amendments to the Constitution of Latvia, which grants the status of second official language to Russian?", and it was rejected by $75.04 \%$ votes with a turnout of $71.13 \%$.

35 Due to increasing dissatisfaction with the Saeima, the Trade Union Confederation launched a constitutional initiative to amend art. 78 and 79, Const., so that preterm elections could be initiated by people's initiative as well. The question of the referendum on the dissolution of the Parliament by the popular initiative was worded as follows: "Are you in favour of adopting the legislative draft on the Amendment of the Constitution of the Republic of Latvia?", and it was approved by 96.99\% votes, yet with an insufficient turnout of $41.52 \%$.

${ }^{36}$ Particularly, an attempt to elevate the status of Russian to second official language failed already in 2011, as the movement 13 January could not collect the necessary 10,000 signatures. Contemporaneously, nationalist parties collected signatures aiming at the amendment of art. 112, Const., to allow only Latvian in public schools. This attempt failed as well in the Collection of signatures on amendments to the Satversme on the education in Latvian.
} 
a private initiative by the above-mentioned "two-stage" process. There is no requirement for notarial certification of the authenticity of the signatures for an initiative on a draft law; in Switzerland and Poland for example, the responsibility for the authenticity of the signatures is taken by the initiative group. The initiative group is registered by the competent national authority and it includes a certain number of voters.

The Latvian Constitutional Court recognized that the requirement for notarial certification of signatures in Latvia complies with art. 1, Const.: such procedure allows ensuring truthfulness and validity of expression of the will of a person to minimize the possibility of influencing the people's legislative process by forged signatures or in another unlawful manner and thereby protect the democratic state system (Judgment of the Latvian Constitutional Court of 19 May 2009, case n²008-40-01; Kārkliṇa 2014). However, the fact that the system complies with the Constitution does not preclude a possibility to evaluate other possible solutions.

Thus, in Latvia, it is possible, as provided for by law since 2009, to take the responsibility for the authenticity of voters' signatures, without asking for notarial certification, ${ }^{37}$ if the framework of a popular initiative group is regulated by law, including its "recognition" by the State, i.e. registration and financial control of the promoter association. Nowadays, the possibility to electronically collect the signatures of the voters can be carried out as well, as is customary in Switzerland, for example.

Lastly, with the amendments to the law on National Referendum, Popular Initiative, and European Citizens' Initiative, adopted by Saeima 8 November 2012, they have been introduced some important innovations to the procedure for exercising voters' right to legislative initiative (Kārkliṇa 2017, 156-169).

Firstly, amendments to the law provide for abandoning the "two-stage procedure" of a popular initiative, enabling the electronic collection of the signatures of the voters. Particularly the people were allowed to certify their signatures not only at the sworn notary but also in the local government in the territory of which their declared place of residence was located, in the Orphan's Court, which performed notarial activities, as well as by the head of the parish or city administration. Indeed, in the transitional period which lasted until 2015, the two stages of collection of voters' signatures were maintained, providing that in the first stage 30,000 signatures should be collected.

Moreover, the main innovation of these amendments is the introduction of the registration of an initiative group that is responsible for a particular draft law. It is clearly defined that it is a competence of the Central Election Commission to assess draft laws submitted by voters and to decide on the registration thereof. These amendments, undoubtedly, make the exercise of the legislative initiative more complicated. This is indirectly proven also by the fact that, following the adoption of the new regulation, a lot of voters' initiatives have been submitted to the Central Election Commission and were registered for the collection of signatures; however, none of these succeeded in gaining the support of one-tenth of the voters within 12 months. Among the amendments that have been strongly criticized is the one, which

\footnotetext{
${ }^{37}$ Law on Amendments to the law on Notary Office of 18 December 2008, which came into force on 13 January 2009. See https://likumi.lv/ta/en/id/59982-notariate-law [Accessed 1 June 2020].
} 
envisages that the initiative group itself (not the Central Election Commission as before) should collect the signatures of one-tenth of the voters, who participated in the latest elections (about 150,000 signatures). Practically, it makes it almost impossible for people to initiate a law.

The new regulation has been contested before the Constitutional Court recognized it as constitutional (Judgment of the Latvian Constitutional Court of 19 December 2012, case $\mathrm{n}^{\circ}$ 2012-03-01, paras. 19.3, 20 and 21), insofar as for almost 11 months, the court did not review an application by members of Parliament challenging the constitutionality of normative incapacity of authorities involved in organizing popular referendum such as the one for introduction of a second official language, to stop further organizing actions, if necessary, in respect of a people's initiative. As a result, a popular referendum did take place and the question of conflict of constitutional norms and the right of creation of such conflict through a popular initiative escalated.

Although the decisions taken by the Constitutional Court to terminate legal proceedings have been criticized in legal science, holding that they could have raised some doubts as to whether the Constitutional Court had sufficiently examined the application in the first stage, deciding on initiating the case, the above-mentioned decision significantly contributed to the Latvian constitutional law. This decision defines the criteria for assessing voters' initiatives, in particular, if they have to be considered as fully elaborated. The assessment criteria indicated in this particular decision are taken as the basis in the practice of Central Election Commission (CVK), as well as in case if a CVK's decision is appealed against before the Supreme court, the court, in assessing the content of submitted draft laws, refers to the criteria defined in this decision by the Constitutional court.

The Constitutional Court of Latvia indicated that authorities involved in the organizing referendum have a right to review the constitutionality of a people's initiative and a right to stop further organizing actions if this should be necessary. However, any authority bringing a popular initiative to a halt has to be aware that its action may be reviewed by either the Department of Administrative Cases of the Senate of the Supreme Court of Latvia or the Constitutional Court of Latvia, depending on authority (Jarinovska 2013). Then, the Satversme may be amended in a national referendum, if such an amendment does not delete any element of the core of the Constitution or does not collide with any element of this core. It is possible to add to the core of the Satversme through a national referendum; however, a different core of the Constitution may be established only by adopting a new Satversme.

Moreover, the amendments of 2012 provide the Central Election Commission with the power to refuse to register a draft law or draft amendments to the Constitution, if the draft law submitted by an initiative group is not fully elaborated in its form or content. Decisions taken by the Central Election Commission reveal that the registration is often refused exactly because a draft law is not fully elaborated as to its content. Particularly, a draft law cannot be considered as fully elaborated in its content, if: it envisages deciding-making procedures that are not regulated by law at all; once adopted, it would collide with norms, principles, and values included in the Constitution; once adopted, it would collide with Latvia's international commitments. 
The question of whether voters have the right to initiate a draft law that pertains to issues referred to in art. 73, Const., on which the people have no right to vote in a national referendum, has caused discussions in Latvian constitutional interpretation for decades (Kārkliṇa 2017, 163-164). The Constitutional Court found a solution to this debate in its decision of 2014 by noting that voters have no right to submit draft laws concerning issues referred to in art. 73. Likewise, voters have no right to submit draft laws that might be incompatible with national values and with the core of the Satversme (Judgment of the Latvian Constitutional Court of 12 February 2014, case $\mathrm{n}^{\circ}$ 2013-05-01, para. 14.4.).

From a comparative viewpoint, in the majority of the countries, submission of a draft law by the voters to the Parliament does not necessarily mean that the Parliament must adopt the law or hold a referendum. Only Switzerland requires a referendum if the Parliament does not adopt the constitutional amendments without applying any change in substance; however, the provision is more flexible than the Latvian one, because electors can vote for both draft law submitted by voters themselves and alternative law adopted by the Parliament.

Therefore, it should be considered, whether the condition that a referendum on a draft law submitted to the Parliament by voters is mandatory or not. In a democratic state, if a large number of voters submit a draft law to the Parliament, the Parliament is obliged to exercise it most carefully as possible, regardless of whether in the case of its nonadoption there is a "threat" of referendum; for a definite abandonment of such draft law instead, there must be very convincing arguments. If the condition that a referendum must be held is maintained, it should be considered a possibility, regarding a referendum on a draft law submitted by voters and rejected by the parliament, to provide for a vote on both draft law submitted by the voters and alternative draft law adopted by the Parliament in Latvia, in a similar way as in Switzerland.

In general, during the pre-war period and after regaining the independence, eight referendums on draft laws, which were submitted by voters and were not adopted by the Parliament, took place in Latvia; however, the necessary quorum was reached only in one case. Therefore, it should be considered either to abandon the quorum for a referendum as set out in art. 78, Const., or to set it up much lower, i.e. one-fourth of the number of the electors as participated in the previous election of the Parliament. By carrying out this proposal, the necessary quorum which is set up for amendments to arts. 1, 2, 3, 4, 6, and 77, Const., will not been changed.

The restrictions set out in art. 73, Const., apply only to the subject of a referendum and not to the subject of a people's initiative, therefore in Latvia, there are no restrictions on the subject of popular initiatives. The preferred solution for Latvia could be ceasing to hold a referendum if the Parliament does not adopt a draft law submitted by voters without amendments in substance, instead of setting limits for subjects of people's initiatives. If there is a need to limit a subject of a popular initiative for practical reasons, such provisions should be expressis verbis included in the Constitution.

Particularly, there is no appropriately regulated mechanism for controlling referendums and people's initiatives in Latvia. Indeed, it is necessary to point out that the law on Referendum, Popular Initiative, and European Citizens' Initiative, should 
include special arrangements for controlling the rule of law of referendums and popular initiatives, entrusting it to the administrative court and setting up one court instance whose judgment cannot be appealed to. In turn, the constitutionality of the signatures collected from the voters and the constitutionality of referendums should be litigable to the Constitutional Court, giving the right to the court to suspend the collection of signatures and the referendum.

Moreover, it is significant to note that all recent people's initiatives (with an average of two submissions per year) are rejected due to insufficient support since it is lower than one-tenth of the electorate and some of them are simply repetitions of previous failures. ${ }^{38}$

In a particular way, from the point of view of their resonance in the Latvian society, I can remember the uniqueness of a recent popular initiative that has been patronized by For Latvia from the Heart Party (No Sirds Latvijai, NSL), which registered a legislative initiative - a draft law - with the Central Election Commission to abolish real estate tax for the only property. Indeed, over the last few years in Latvia, the real estate tax has been rising dramatically, compared to Estonia and Lithuania, where the tax for the only property has been abolished. ${ }^{39}$ Lastly, regarding the EU migrant quota relocation - which was the subject of a manipulative referendum held in Hungary on October 2016 (Ratto Trabucco 2017, 192-197) - the same NSL Party, particularly active in the use of Latvian direct democracy tools, stood out against them, at the same time they did not see the need to call for a referendum on this question, because apparently the compulsory quota system, even though unfair, does not represent any direct threat to the Latvian society.

\section{The referendum on the dissolution and recalling of the Parliament}

The essence of art. 48, Const., ${ }^{40}$ analysing it in conjunction with art. 50 Const., ${ }^{41}$ which provides for the removal of the President if the voters are against the dissolution of the Parliament, is not only to entitle the voters to dissolve the Parliament if they are not satisfied with the Parliament's work but also to entitle them to solve a possible conflict between the Parliament and the President. No quorum is set for the referendum on the dissolution of the Parliament embodied in art. 48, Const.

\footnotetext{
38 Initiatives $\mathrm{n}^{\mathrm{o}}$ 20150918-008, 20160916-003 and 20170918-028 on the draft law on repealing the law Amendments of the law on National Referendums, Initiation of Laws and European Citizens' Initiative adopted on 8 November 2012.

${ }^{39}$ Initiative $\mathrm{n}^{\circ}$ 20170421-012 on law Amendments of the Law on Immovable Property Tax adopted on 4 June 1997, with subsequent amending laws.

40 Art. 48, Const., declares: "The President shall be entitled to propose the dissolution of the Parliament. Following this proposal, a national referendum shall be held. If more than half of the votes are cast in the referendum in favour of the dissolution, the Parliament shall be considered dissolved, new elections, which must be held no later than two months after the date of the dissolution of the Parliament, shall then be called".

${ }^{41}$ Art. 50, Const., declares: "If more than half of the votes are cast in the referendum against the dissolution of the Parliament, then the President shall be deemed to be removed from office and the Parliament shall elect a new President to serve for the remaining term". See Ciammariconi and Di Gregorio 2005, 1419.
} 
In turn, art. 14 , Const., as modified in $2008,{ }^{42}$ provides for the right of the people to initiate the recalling of the Parliament as well as to hold a referendum if a proposal of its recalling is made. Thus, one-tenth of the electors have the right to express their dissatisfaction with the Parliament's work, by initiating a referendum on its recalling. In turn, the purpose of the referendum on the recalling of the Parliament is to hand on to the people the task to decide whether the Parliament they have elected in the direct election still deserves their confidence or not insomuch that it has to be recalled.

Art. 14, Const., also provides that the right to initiate a referendum regarding the recalling of the Parliament may not be exercised one year after the convening of the Parliament and one year before the end of the term of office of the Parliament, during the last six months of the term of office of the President, as well as earlier than six months after the previous national referendum regarding the recalling of the Parliament. The purpose of such time limits is to promote political stability. Moreover, the voters cannot initiate the recalling of the newly elected Parliament during the first year of its term of office, which prevents that the recalling of the Parliament is misused for revising the election results, instead of being aimed to evaluate the Parliament's work.

In the Latvian history, the Saeima has already been dissolved, although not by the Constitution, but rather with the coup of 1934, leading to the suspension of the Satversme's activities. It should be noted that in 1927, the initiative on a draft of the law on the Recalling of the II Saeima of the Republic of Latvia did not succeed because the 1,000 necessary signatures were not collected, so it was not possible to begin officially the collection of voters' signatures (Pleps 2003, Kārkliṇa 2013).

After Latvia's regained independence and until 2011, the mandate of Saeima's representatives has never ceased before its natural expiration date, even though there have been several frictions among institutional entities (Pryce 2012). Since 2013, there have been only three popular initiatives for the recall of the Parliament, yet with insufficient signature support. ${ }^{43}$

The first and unique presidential dissolution referendum arose from a political clash of opinions between President Zatlers and the parliamentary majority. Central Election Commission announced the referendum on the premature dissolution of the X Saeima based on the President's Order On the Proposal on the Dissolution of the Saeima (Par Saeimas atlaišanas ierosināšanu, 28 May 2011). Besides, it should be reminded that, previously, the same President, in his legislative initiative, had proposed to specify the mechanism for dissolving the Parliament and providing that the Head of State would not have the right to dissolve the Saeima, if less than three months remain before the

\footnotetext{
42 The law of 8 April 2009, supplemented art. 14, Const., formulating its para. 1 as follows: “Not less than one-tenth of the electors have the right to initiate a national referendum regarding the recalling of the Parliament. If the majority of the voters and at least two-thirds of them who participated in the last elections of the Parliament vote in favour, then the Parliament shall be deemed recalled (...)". The amendments to art. 14, Const., came into force with the convening of the X Saeima on 2 November 2010.

43 Initiation of recalling of the Saeima of 23 November 2016; Initiation of recalling of the Saeima of 6 November 2015; Initiative on Organizing a National Referendum on dissolution of the XI Saeima of 28 May 2013.
} 
expiry of his term of office. However, no amendments regarding this issue were introduced in the Constitution (Rodina 2011, 1310-1312).

Indeed, a significant and important aspect to note is that, back then, Zatlers' mandate came to its end. Indeed, before the referendum, there was the presidential election and the For a Good Latvia! Party (Par Labu Latviju!, PLL), which at first was willing to support the outgoing President for a second term, withdrew its support right after the referendum (Baldin 2012, 11). Consequently, the Parliament doesn't confirm Zatlers as President and elected the antagonist candidate Bērziņš. However, some month later the electors voted widely in favour of the closure of the X Saeima in the dissolution referendum without reaching the quorum. ${ }^{44}$ Thus, the voters shared the opinion of former President Zatlers to dissolve the Saeima but the parliamentary majority "punished" the same President with the non-re-election.

The dissolution of the Parliament, as provided by art. 48, Const., has been strongly criticized by the President's Constitutional law Commission (Valsts prezidenta Konstitucionālo tiesìbu komisija, Constitutional law Commission of the State President, 2008) although, in general, the decision of President Zatlers to dissolve the Saeima has been very positively perceived in society. The inefficiency of this mechanism derives by the fact that the Constitutions of other countries do not include similar stratagems for dissolving the Parliament. President Zatlers repeatedly urged the Parliament to amend art. 48, Const., by entitling to the President the independent right to dissolve the Parliament without holding a referendum. Although it is arguably which limits have to be set up regarding the President's right to dissolve the Saeima, the author agrees that a referendum has to be held in this case: theoretically, if Saeima is elected by the people, the people should also be the ones that dissolve it. However, the referendum should not be linked to the voters' choice between the dissolution of the Parliament and the removal of the President. Finally, the efficiency of the referendum set out in art. 48, Const., has been particularly questionable since November 2, 2010, when the amendments to art. 14, Const., which provides voters with the right to initiate the recalling of the Parliament, came into force. ${ }^{45}$

Similar cases of the referendum embodied in art. 14, Const., cannot be found in other countries. However, art. 14, Const., should be taken with criticism, since it requires a disproportionately high quorum, meaning that the Parliament must be deemed recalled if at least two-thirds of the voters who participated in the last elections of the Parliament vote in favour. In general, the quorum requirement for such a referendum should be viewed positively. Nevertheless, a too high quorum threshold should be avoided, since there could be the risk that the Parliament may not be recalled if the required quorum is not achieved, even though the majority of the voters expressed their will in favour of that.

\footnotetext{
44 The question of the referendum on parliamentary dissolution was worded as follows: "Are you in favour of the dissolution of the $10^{\text {th }}$ Saeima?" and it was approved by $94.30 \%$ of votes with a turnout of 44.73\%. See Dau 2011. Available from https://users2.unimi.it/dirpubesteuropa/2011/09/lettoniareferendum-sullo-scioglimento-del-saeima/ [Accessed 1 June 2020].

${ }^{45}$ Law of 8 April 2009. See https://likumi.lv/doc.php?id=191210 [Accessed 1 June 2020].
} 


\subsection{The parliamentary dissolution referendum in a comparative European view}

The anticipated parliamentary dissolution represents the peak of an irreconcilable contrast or a political, both executive and legislative, impasse, or/and even a contrast among the parties attending to the Parliament (Baldin 2012, 9). Such a situation prevents the governing body under consideration to exercise its regular activity.

Usually, presidential systems grounded on the separation of powers do not rely on the possibility to re-elect prematurely members of the Parliament. In those kinds of systems, both Head of State and legislative power are legitimated by popular vote. A separate discourse needs to be entered into for presidential systems representing a "warped" implementation of the concept of presidential government. Examples include the event of parliamentary dissolution carried out by the President, which turns out to be a stratagem that produces a certain imbalance among various powers; as a result, the one who benefits the most of such a situation is precisely the President himself (Volpi 1983, 48-49), as it happens in Belarus, Russia, and Uzbekistan.

In parliamentary and semi-presidential systems, the event of an anticipated dissolution is recognized in almost every country; formal juridical ownership is up to the Head of State, who takes the decision or, in any case, signs the dissolution document, while substantial juridical ownership is up to the President (in semi-presidential systems) or the President in partnership with the government (in most cases), or even to parliamentary majority (ultimately opting for self-dissolution; Volpi 1983, 79-86, Frison-Roche 2005, Frosini 2008, 297-304). In politically homogeneous systems, (where the conflict between majority and government is quite a more complicated), it is the government that manages the tool of anticipated dissolution, intending to encourage the stabilization of the ruling party. In politically heterogeneous systems, where the parties tend to solve every crisis within the parliamentary context, anticipated dissolution takes the shape of a consensual stratagem used by the parties themselves to prove the consistency of their representation (Markesinis 1972, Lauvaux 1983, De Vergottini 2013, 561-562).

The most singular examples include the dissolution prevision provided by the Austrian Constitution (pursuant to art. 29, para. 2, Const., in addition to an eventual decision to be taken by the President, pursuant to art. 29, para. 1, Const.) and by the Basic law on the Israeli Parliament (arts. 34-36). The decision taken in Moldavia turns out to be quite unusual as well; indeed, it was decided to entrust the task to verify the causes underlying parliamentary dissolution ${ }^{46}$ to the Constitutional Court, who would supply a prior opinion to the President. ${ }^{47}$ However, it is necessary to highlight that in

\footnotetext{
46 The Moldavian Head of State can dissolve the assembly, after consulting the Parliament, if it is not possible to form the government or in the event of an impasse lasting three consecutive months in the process of adopting a new law. The Head of State can also opt for parliamentary dissolution after a second unsuccessful no-confidence vote in the government. Limits to this measure are: declaration of a state of national emergency; declaration of martial law; state of war and the period consisting of the last six months of the presidential mandate (the so-called "white semester"), (art. 85, para. 4, Const.). On the contrary, in the direct presidential system which was previously in force in the country, it was possible to carry out the parliamentary dissolution even during the white semester, in the event that the Parliament did not manage to elect the new Head of State (art. 78, para. 5, Const.).

47 According to art. 135, para. 1, lett. f), Const. and to the opinion of 21 September 2010, no. 4, the Moldavian Constitutional Court ascertained that the decision to dissolve the legislative body was due to
} 
2000, a constitutional innovation was introduced as regards the election procedure of the Moldavian Head of State, causing a transition from a direct election system to a mediated one through the institution of the Parliament. ${ }^{48}$ Nevertheless, in 2016 such innovation was held to be unconstitutional, therefore the direct presidential system was eventually restored after a twenty-year-long period of parliamentary appointment. ${ }^{49}$ It follows that the dissolution prevision finds a better ratio in the governmental arrangement which was in force ante 2000 as well as in the current one, which is presidential. It is understandable that it may arise the need to impose given limits to an exaggerated discretion the President may take advantage of, leading in the end to a shift towards authoritarianism. ${ }^{50}$

In turn, the Latvian situation appears to be quite unusual too, being an example sui generis within the comparative European field. It is fundamental to remind that the spread of direct democracy tools, which occurred in the period following the end of World War II, is related to a negative phenomenon, i.e. the stabilization and the institutionalization of national parties. That being said, the Constitution of 1922 reflects the historical-juridical tradition of the country, which conceives legislative bodies as the cornerstone underlying all governmental institutions, while the referendum is viewed as an antidote to deviations from proper parliamentarism. From the perspective which is of major importance in this analysis, it should be remarked that the Head of State assumes a fundamental leading role. It seems like the figure of the Latvian Head of State was shaped following the example set by the German counterpart as provided for in the Weimar Constitution (yet without relying on popular legitimation, since the Head of State is elected by deputies). The Head of State is considered as a foreground player, who can guide the government towards a political direction potentially contrasting with respect to the one opted for by the parliamentary majority. In order to avoid deadlock situations between the Head of State and the unicameral assembly, it is possible on the one hand, to hold a dissolution-

the failure of the Parliament at finding an agreement in order to elect a new Head of State, available from https://lex.justice.md/index.php?action=view\&view=doc\&lang=1\&id=336083 [accessed 1 June 2020] and the Report on the Exercise of Constitutional Jurisdiction in 2010 (Constitutional Court of the Republic of Moldova 2011).

48 Art. 78, para. 3, Const., modified with Law no. 1115-XIV of 5 July 2000, then, in 2016, held to be unconstitutional, provided that the President could be elected only through a three-fifths majority out of the total of all members composing the Parliament.

${ }^{49}$ Judgment of the Moldavian Constitutional Court, 4 March 2016, n. 7. As a result, amendments to art. 78, paras. 1, 3, 4 and 5, Const., issued on 2000, were held to be unconstitutional; it was exactly through the above-mentioned amendments that the indirect election procedure of the Head of State, for which responsibility lies with the Parliament, was introduced in the country. See Krapivnitskaya 2016, 2-4.

${ }^{50}$ Similar provisions formally exist in the Constitutions of Belarus and Uzbekistan as well, both countries in which presidential systems are in force - though only de facto in compliance with the rule of law. In these countries, the declaration of parliamentary dissolution is carried out after each respective Constitutional Court provides for a preliminary opinion. Indeed, Constitutional Courts should ensure the neutral stance of the President while deciding whether to dissolve the Parliament or not. In Belarus, the judges, upon request of the Head of State, are responsible for spotting habitual, serious infringements of the Constitution that the Parliament may carry out (art. 94, Const.). In Uzbekistan, the Constitution provides that the Head of State can dissolve the Parliament in agreement with the Constitutional Court (art. 95, Const.), in the event of irreconcilable conflicts among the deputies which may hinder the regular activity of state institutions or in the event that the Parliament takes several decisions which infringe the Constitution. 
referendum concerning the Saeima and, on the other hand, to take action towards the President's parliamentary suspension (Pollock 1923).

Both formal and substantial juridical ownership as regards anticipated dissolution is up to the Head of State, whereas political ownership is up to the electorate. It is exactly the electorate that may decide to put a potential anticipated end to the legislature. In that way, the Latvian system stands out concerning all other juridical systems in which political ownership is generally ascribable to the Head of State and the parties. ${ }^{51}$ Additionally, according to Burdeau, the prevision of the President's parliamentary revocation would render the dissolution power meaningless. This would be because a President liable for suspension owing to political matters would not be of any support to the government in the event of a conflict with the Saeima since an important threat of retaliation would impend over him.

It is the case of a so-called recall referendum (Welp 2018, 451-463) since it is supposed to serve as a safety valve of the whole juridical system in the event of a contrast between the electorate and its parliamentary representatives, or among supreme judicial bodies. The people play not only an arbitral role, but they can also legitimate the power, not to mention their participation while settling political conflicts. It must be certainly admitted that the above-mentioned countries have been affected by many political crises, yet it shall be deemed that other particular circumstances influenced the significant response in terms of referendums of a similar nature that have been launched lately. As regards Latvia, there was a factual circumstance, i.e. the imminent end of the presidential mandate; as regards Romania instead (with the referendum of revocation of the Head of State, lastly in 2012), there was a circumstance of law, i.e. the abolition of the possibility to carry out the parliamentary dissolution.

Also, other post-socialist systems establish the recall referendums. The Constitution of Estonia of 1922 refers to the previous constitutional texts of 1920 and 1938 (Nutt 2005) with various democracy direct tools. Unlike in the past, the referendum of parliamentary dissolution is modified as a consequence of the rejection of a draft law. The art. 105, Const., it stipulates that the assembly has the right to submit a draft law or other national issues to a referendum. The Rules of Procedure and Internal Rules of the Estonian Parliament (Riigikogu) provide for the majority of the vote to activate the referendum procedure, so this is certainly not a guaranteed tool for the parliamentary minorities (Riigikogu Rules of Procedure and Internal Rules Act).

The Estonian recall referendum was never activated. Indeed, it raises doubts that this corrective tool of parliamentarianism can have practical application (Ciammariconi and Di Gregorio 2005, 1419). Does it raise perplexity why the majority of the assembly should hold a referendum with the risk of bringing the end of the legislature if the people express themselves against the parliamentary decision? Furthermore, is this variant in the strict sense still attributable to the family of recall referendums? Or perhaps it represents a hybrid to be included in the trend, found in several systems, to use referendum for the important decisions of national politics, thus overcoming the subdivision of the electorate by party's divisions (De Vergottini 2013, 407).

\footnotetext{
${ }^{51}$ About political ownership of the parliamentary dissolution, see Volpi 1983, 169-209.
} 
The revocation referendum by art. 95, Const. Romania of 1991, which had two precedents in 2007 and 2012 (Băsescu's cases), moves away from the Weimarian archetype in various ways. Indeed, the procedure is activated in the cases in which the President has committed serious crimes in violation of the constitution. The political responsibility of the first citizen is combined with legal responsibility, on which the Constitutional Court is obliged to make an obligatory but non-binding opinion. The President is suspended from office if the Parliament in a joint session, after the opinion of the court, votes in this direction by an absolute majority. Within thirty days of suspension, the President of the Senate, as ad interim Head of State, is holding a referendum so that the voters can express their views on the revocation of the suspended president. However, the dissolution of the chambers is not foreseen in the hypothesis of "absolution" of the President: during the work of the constituent assembly a proposal was formulated in this sense but was not accepted (Tănăsescu 2008). Therefore, in the event of a favourable vote towards the Head of State, the organs involved in the political conflict remain in place, not providing for a way out of an institutional conflict that should instead constitute the ratio of the original institution (Baldin 2008, 72-74, King and Sum 2011, 72-74, Bosioc 2013).

With the constitutional revision of 1999, the art. 106, Const. Slovakia has introduced the recall referendum of the Head of State, also transforming the presidential election from parliamentary to popular because of the difficulty of the assembly to reach an agreement on the presidential candidate. Instead of lowering the quorum after a certain number of null votes - as envisaged in Italy -, it was preferred to delegate the choice of President to the people, without necessarily establishing a strictu sensu semipresidential government system. The referendum is activated by a majority of the three-fourths vote of the National Assembly and in case of rejection requires parliamentary dissolution. It is, therefore, imitation of the Austrian solution of 1929, including the system of responsibility as a corollary of presidential powers and therefore also the recall referendum, without fully assessing its usefulness or practicability. However, the Slovak presidential recall referendum hypothesis has not had any concrete implementation to date (Baldin 2008, 66).

The analysis carried out summarizes the characteristics of the recall referendum in a European comparative perspective. First of all, it highlights the nature of their activation, which is optional and not mandatory, and of the functions of control and legitimization of power. Moreover, the effects of voting constitute such referendums as decision-making, having a legally binding effect. On the other hand, there are no other elements of uniformity, also because of the hybridizations referred to in these referendums in the various legal systems. These are consultations that can be activated both from below and from above, that is from the people in some cases, and from the President or Parliament in others. They can determine the loss of the President's mandate (Weimar Const., Austria, Iceland, Latvia, Romania, and Slovakia) or that of all the parliamentary representatives (Weimar Const., Austria, Estonia, Iceland, Latvia, and Slovakia), and not always it deals with alternative solutions, as in the cases of Estonia and Romania. If the object of the vote is political in nature, politicity can also be expressed in the approval of a legislative act (Baldin 2012, 8). 
Moreover, the initiative from above and not from below is the element that most differentiates the recall referendum by German origin from other types of revocation of the elected, such as the Abberufungsrecht in seven Swiss cantons, ${ }^{52}$ the dissolution of the Landtag provided in six German Länder, ${ }^{53}$ the withdrawal (Odwołanie) of local selfgoverning bodies in Poland (Art. 170, Const. Poland and Act 15 September 2000, on the local referendum; Wilk 2013, 11-26), the recall of the North American Member States (De Pretis 2004) and the revocatoria de mandato of the Latin American area (Fara 2012). Their ratio is not based on the premise of healing a conflict within constitutional bodies, but on the idea that the electorate has the right to prematurely terminate the mandate of individuals and/or collegial bodies, by the principle of people's sovereignty (Baldin 2012, 9).

In the final analysis, it can be said that, when it comes to recall referendums, a very subtle risk may arise; it is a risk concerned with their redundancy, as supreme judicial bodies could abuse the power to launch such referendums, or, more precisely, supreme judicial bodies could take advantage of the presumption that, thereby, they are not taking any risk at all (Cazejus 1925, Helstein 1930, De Francesco 1933, 335-336, Burdeau 1950, 262-264).

In Latvia, the above-described matter emerged when sanctions could not be imposed to the Head of State, so there were no grounds for fearing that the election result could be somehow negatively affected nor that the Head of State could be removed from office. The fact remains that, in doing so, the outgoing President Zatlers missed the opportunity to see his office renewed a second time (Baldin 2012, 14).

As to the effect produced by the dissolution-referendum on the system of government, it should be noted that the assembly was reconvened in compliance with democratic principles. As a result, the institution took the same shape as conceived by its founding fathers back to 1922, i.e. as a tool available to the President for solving certain political situations, promoting popular sovereignty as well. As instead to Burdeau's statement on the topic of presidential revocation by Saeima as a deterrent of dissolutionreferendums, it should be pointed out that the procedure expounded in art. 51 Const., at its propositional stage, requires the approval by not less than half of all members of the Saeima, whereas its repeal requires that two-thirds of the votes cast are in favour. It is the case of a quorum that might be achieved if the President does not comply with his institutional duties. ${ }^{54}$ However, such a quorum threshold appears to be too high in the event that the conflict with the Parliament originates in political matters of a different nature, for which the Head of State could find a solution by turning to the legislative and, at the same time, seeking support in the public opinion, as it occurred in the situation under consideration (Baldin 2012, 15).

\footnotetext{
${ }^{52}$ Cantons of Bern, Lucerne, Schaffhausen, Solothurn, Ticino, Thurgau, and Uri.

${ }^{53}$ Länder of Baden-Württemberg, Baviera, Berlino, Brandeburgo, Brema, and Renania-Palatinato.

${ }^{54}$ The same quorum was established by art. 54, Const., in case of the opening of a criminal proceeding against the President.
} 


\section{The set of issues on the local and consultative referendums and collective application}

In federal states, referendums are often held at the federal level (i.e. at the regional level in Belgium, Italy, and Spain, in Austrian and German Länder, as well as in Swiss Cantons), whereas in unitary states - at the local self-government level. Besides, in countries made up of several self-government levels, referendums may be held at each of them. Unlike nationwide referendums, regional and local referendums are often not embodied in national Constitutions (Croatia, Czech Republic, Denmark, Estonia, Finland, Ireland, the Netherlands, Romania, and Sweden), even though they can be legally held, even based on legislation issued by local authorities.

It has been recognized that direct democracy in Europe is much more effective at lower levels (Auer 2001, Schiller 2011, 10). The role of regional and local referendums has been particularly emphasized in the decision-making process concerning the borders of federal subjects or local self-governments; it is recognized by the European Charter of Local Self-Government issued by the Council of Europe ${ }^{55}$ as well. The constitutions of several European countries, i.e. the Constitutions of Bulgaria, Czech Republic, France, Germany, Italy, Portugal, Slovakia, and Slovenia, provide for a mandatory referendum regarding the change of the borders of federal subjects or local self-government units. It is typical for regional and local referendums in Europe that they are often not binding but consultative (Austria, Finland, France, Spain, and Sweden). In several countries, both binding and consultative regional or local referendums are held.

In Latvia, since 2005, art. 61 of the law on Self-Governments of 19 May 1994, with subsequent amending laws, includes provisions regarding a public discussion on the issues of the autonomous competence of self-government. The outcome of a public discussion is permissive, that is a local authority is obliged to collect and evaluate opinions of the residents but the outcome of the discussion is not formally binding. A public discussion must be held in Latvia regarding changes in the administrative borders of the local self-government and on local development programs and spatial planning; besides, a local authority must hold a public discussion on construction in cases set out in the construction law. A public discussion on other issues is optional, meaning that it is held only if it is initiated by authorized persons. At the same time, a public discussion may be initiated not only by governing bodies or officials of the selfgovernment (municipal council or its chairperson) but also by residents.

The public discussion in Latvia should not be regarded as a local referendum, as residents have the right to express their opinion on a given issue both "orally and in writing" (art. 61, para. 2), while a characteristic feature of the referendum is casting a vote. However, the difference is not always very essential in practice, because a question submitted for public discussion may be put in a way that the residents can either support it or reject it. Since 2008, the law on Self-Governments also includes provisions regarding a local referendum (art. 61, para. 3), yet that has not come into force, since the law on the order of holding a local referendum has not been adopted, as in other Baltic countries.

\footnotetext{
55 The European Charter of Local Self-Government drawn up by the Council of Europe was signed and ratified by Latvia on 5 December 1996; it came then into force on 1 April 1997.
} 
However, the political importance of acknowledging public opinions appears to be widespread in local elites, especially as regards the issue of the territorial administrative reform. In some local governments - i.e., in Riga - public hearings have been organized to both conceive and plan land use developments and the construction of large buildings (Kaufmann and Dane Waters 2004, 77, Vilka et al. 2006, Ruus 2011).

Whether provisions regarding a local referendum have to be included in the Latvian legislation, is a question that requires a political decision. On the one hand, direct democracy exists at the level of local self-government all over Europe and it has been found very effective. On the other hand, the local public discussion, which is also a form of involvement of residents into a decision-making process, exists in Latvia. The only essential feature which distinguishes a public discussion from a local consultative referendum is that participants in a public discussion "may orally and in writing express their opinion on the issue of the public discussion". Thus, the objectives of a public discussion are wider - local self-government can also gain motivation to take action from the opinions expressed by the residents on a particular issue or gather suggestions for solving a particular problem.

In Latvia, all types of existing referendums are embodied in the Constitution. However, if provisions regarding local referendums were included in the Latvian legal system, the Constitution would not be necessarily amended as a consequence. Such a conclusion can be drawn, firstly, because the Constitution does not provide for a legal status and a precise scope of competencies of local self-government, but it only sets up some questions related to self-government' work, secondly, provisions regarding a local referendum are often not included in the constitutions of other European countries as well. Thus, the local referendum can be an example of the development of referendum tool (Ciammariconi and Di Gregorio 2005, 1423-1424).

Furthermore, if the Latvian legal system establishes a local referendum, its outcome should not be binding. At the local level, the consultative referendum is typical for European countries. A local self-government is obliged to take into account the outcome of a local referendum and to provide argumentation, if a decision which is not in line with the outcome of the referendum is taken; however, a local self-government should have the right to take also into account other considerations which, in some cases, may be more important than public opinion.

Both Latvian Constitution and legislation do not provide for nationwide consultative referendums, that is referendums whose outcome is not binding for public authorities. There are nationwide consultative referendums in several European countries (Austria, Belgium, Denmark, Finland, Lithuania, Netherlands, Poland, Spain, and Sweden). The advantage of consultative referendums is that they allow the voters to express their opinion on important issues, but at the same time they do not formally bind public authorities, that is they may take a decision which is not in line with the opinion of the voters if there are reasonable considerations for doing so.

It would be advisable that the Latvian legal system provides the possibility to hold nationwide consultative referendums. As the Latvian term tautas nobalsogana refers to a referendum whose outcome is binding, as for consultative referendums, it might be used a term like tautas aptauja, to refer to the consultative (unbinding) nature of the referendum. Furthermore, if a referendum held by art. 77, 72, 68 or 78, Const., does not 
reach the quorum, but a significant number of voters have participated and votes cast in favour or against are overwhelming, the outcome of a referendum should be anyway considered by the Parliament.

Collective application, included in the Rules of Procedure of the Saeima and affected by the above-mentioned amendments since 2 February 2012, should not be considered a subtype of the popular legislative initiatives of the electorate, however, it still is, in a broad sense, a specific, Latvian form of direct democracy. The main difference from the popular initiative is that the voters submit a fully elaborated draft law to the Parliament, while the collective application has a free form and it contains law proposals. Indeed, the right to launch collective submissions derives from the right to submit petitions to state institutions (art. 101, Const.) by citizens older than 16 years. If the initiative is supported by 10,000 signatures, the proposal is then submitted into Saeima for consideration, but there are no legal consequences if the Parliament doesn't adopt the submitted idea that it is other important difference from electorate initiatives ex-art. 78, Const.

That being said, the collective application is an appreciable tool of direct democracy, as it promotes the involvement of the citizens in public affairs as well as their awareness and interest in issues of national importance. Furthermore, the Latvian Internet portal for collective applications ManaBalss.lv is quite popular and it is used to collect signatures for lots of applications. Particularly, it is not managed by public institutions and it was created in 2010 as a platform for community initiatives in which every citizen of Latvia could put forward his/her initiative and collect signatures for delivering it to the Saeima. ${ }^{56}$ Like collect the most valuable ideas by people from one of the largest and most successful grassroots participation projects in Latvian history, but a similar web portal in Estonia has launched already in 2001. ${ }^{57}$

The portal is a remarkable initiative for the development of direct democracy and puts Latvia at the forefront of European efforts to change the forms of political participation on the Internet (McGrane 2013). In ManaBalss.lv, the identity of each voter is verified by the registered Internet bank of Latvia with security warranties. ${ }^{58}$ Initiatives can be launched and signed by any Latvian citizen who has reached the age of 16 years and each initiative signed by at least 10,000 citizens meeting the Saeima's legal criteria, will be discussed in the Parliament.

\footnotetext{
56 The portal was created in 2010 by two young Latvians - the businessman Christoph Blaus and the marketing expert Janis Erts - with the promotion of the first initiatives in the Saeima.

${ }^{57}$ In Estonia, the web portal Osale.ee allows the people to participate in open consultations on issues of all kinds and to make suggestions to the government for improving life standards; it was launched in 2008, putting itself in continuity with the tradition of public participation of the previous citizens portal Täna Otsustan Mina (Today, I Decide) or TOM, active since 2001 at https://www.eesti.ee/tom [accessed 1 June 2020]. In Lithuania, there is only a web portal, allowing the people to initiate any proposal for improving the state organization and for proposing any idea concerning the Lithuanian centennial jubilee, in https://www.idejalietuvai.lt [accessed 1 June 2020].

${ }^{58}$ The security is provided by the banking system: upon successful authentication, Internet Banking sends a person's name, surname and personal identity number to ManaBalss.lv, where personal data is stored in protected databases. A person can make one vote for each initiative and only the first name and surname are publicly available. At the Saeima's request, the database of signatories will be compared with the Citizens Register, which will be able to verify the authenticity of all signatories through its database.
} 
In June 2011, the newly created website ManaBalss.lv could initially rely only on two initiatives - Opening Offshore and Opening the Saeima!. A week after the start of the activity of the portal, the Saeima's extraordinary session embraced the first draft law coming from the portal on the opening of offshore and it was agreed upon a positive evaluation at the first reading: within a week, the bill was adopted. Such results and the subsequent activities of the portal have made ManaBalss.lv, a turning point in public communication and cooperation with the Saeima.

The portal is in the continuous technical and content improvement and development with the support of the authors of the initiatives. It also promotes new digital participation tools as well as the participation in community discussions. Surely, ManaBalss.lv represents an example to follow from other countries in the world, to reach the heart of decision-makers, starting from the very ideas of the electorate.

Raising awareness in the population, encouraging it to engage in political decisionmaking, is one of the most important features of a democratic society. Even today, it is obvious in Latvia that politicians have to explain their decisions and, before to their adoption, they have to consult the population. Then, active citizens and civil society interested in political processes can not only speak their mind on ideas put forward by politicians but, in turn, they can also propose ideas on their own.

So far, there has been little development of such community-initiated laws because, in the very short tradition of democracy, as well as in administrative obstacles that need to be resolved to propose a referendum. The referendum process is expensive and inflexible - the Saeima cannot legally adjust the submitted initiatives -, besides, quite a few proposals among those put forward would deserve to enter the Saeima's agenda.

Therefore, the right to legislative initiative, which ManaBalss.lv embodies, aspires at granting Latvian citizens new opportunities to get involved in the activity of the Saeima. Particularly, the web portal supports the idea of introducing in Latvia a new tool of direct democracy like the agenda initiative. This would allow every idea that can potentially collect the required number of signatures (i.e., 10,000 signatures) entering in that way the Saeima's agenda. Submitters would have the right to address to the Parliament in plenary, naming the reasons for the initiative. The Saeima could then either reject the idea by voting it or readdressing it to the responsible committee for further development.

Such a possibility would allow Latvian citizens not only to influence the Saeima's agenda but also to raise awareness about the Parliament's activity, to promote civic monitoring of parliamentary work, to develop civic participation capacities as well to allow elected representatives of the people to be conscious of important social questions.

\section{Conclusive remarks}

Latvia and Baltic countries are rich in direct democracy tools that are automatically summoned - by both public authorities and citizens. The majority of popular referendums held in Latvia refer to the top-down mechanism of direct democracy, which is, in fact, the least citizen-friendly of all direct democracy tools. Public authorities decide on both the issue and the period in which the referendum is going to 
be held; citizens cannot directly take public decisions. The second major group of popular referendums is held from below, though most of these take place as a consequence of a decision taken by political parties and not by citizens as the one about the access to EU (Uleri 2003, 274-277, Ciammariconi and Di Gregorio 2005, 1424).

Despite the high amount of top-down referendums, it should be noted that referendums promoted by the authorities (as well as in other Baltic countries) have been hardly ever used in Latvia to empower governing majorities or the President, trying to extend their term of office and altering in that way the balance between the Government/President and the Parliament, as is the case of less democratic societies (i.e. Belarus, Kazakhstan, Uzbekistan, and Venezuela). Latvian top-down referendums have been instead used strategically for partisan purposes to strengthen the parties' public image before parliamentary elections were carried out.

Indeed, three main reasons explain the absence of empowering of the use of referendums. The first one consists of the criterion used to control the features of a referendum. According to checks and balances, referendums from above are mainly framed and triggered by different political actors; alternatively, referendums depend on their joint action. Secondly, as it occurs in citizen-initiated referendums, further procedural settings, such as restrictions on subject matters (i.e. the presidential plebiscite can be launched only to recall the Parliament) and turnout and approval quorums also diminish the effect of referendums from above. A further reason for the absence of empowering of the use of referendums results from the party system (i.e. Latvia's volatile multi-party system) because volatile and polarized party-system make it difficult to reach agreements on critical resolutions (Sikk 2005).

Citizen-initiated referendums were the main type of referendum held in Latvia that was triggered by associations camouflaging political parties. As with referendums from above, citizen-initiated referendums were exploited also as strategic tools to bypass the Parliament and to eventually get the necessary popular support. However, citizen initiatives were also an important tool in promoting party campaigns, especially by holding them on the same day as the elections. In this regard, such referendums were even more exploited in comparison with the attempt to gather the required popular support on a specific issue.

About their outcome, mandatory referendums were the most effective one, since they all happened to be successful. Regarding the areas of concern of such referendums, it is not surprising that, in Latvia, they mostly dealt with issues of state organization, including national identity, legal and political systems, and citizens' rights. Referendums were helpful tools in overcoming the Russian-Soviet trauma and reestablishing the country's crucial legal framework, particularly during the transitional period. Indeed, after the end of the Soviet era, Latvia had to, on the one hand, build and expand democracy and, on the other hand, urgently secure their nation from the allogeneic Russian community (Duvold 2010, 92).

Forcedly, in Latvia (in Estonia as well), the re-establishment of the nation-state happened, in retaliation, at the expense of Russian-speaking minorities living in the country as a consequence of the ethnical assimilation pursued by the Moscow government. This persistent ethnic cleavage emerges in each country from all the unsuccessful citizens' initiatives, whose failure was already clear during the signature 
collection procedure. A second important referendum subject area concerned economic questions, while other policy areas were seldom or have never been subject to referendums.

The possible reasons for the low performances of direct democracy in Latvia must be evaluated concerning the procedural hurdles that diminish the will of the people and affect the nature of the popular veto. Indeed, there are several formal factors that have to be taken into account when drawing up a direct democracy mechanism, like signature thresholds, collection periods and places, turnout and approval quorums, restriction of subject matters, type of authorities' involvement and legal consequences of referendums. The role played by civil society and education cannot be neglected as well. Further aspects, such as finances and transparency in ballot campaigns, are also essential in achieving fair direct democracy procedures that can realize their full potential (Kaufmann et al. 2010, 92-94). Moreover, the practice and the influence of the national referendum tools on the Latvian government system has demonstrated a very limited impact except, of course, for the peculiar referendum on the dissolution and recalling of the Parliament by Head of the State that poses in "rubbing" these two organs. Indeed, without a kind of "white semester" rule (as in Italy; Art. 88, para. 2, Const. Italy; Pollicino 2018) for the last six months of the President's mandate - when the Head of the State cannot dissolve the Parliament and call a new election - the Latvian President can use hypothetically the recall referendum for a re-elections from the new Parliament, as apparently in the Zatlers's case but without success.

In Latvia, although almost all direct democratic institutions are available, including the right to people's initiative for constitutional and legislative amendments, there is a weakness in the restrictions on subject matters. It is the case of issues regarding the budget, as well as laws concerning loans, taxes, customs duties, railroad tariffs, and military conscription, which are excluded from the process of direct legislation. About citizens' initiatives, Latvian rules state that only elaborated drafts can be submitted to a national referendum. General suggestions that would also enable citizens without legal knowledge to launch a legislation initiative are not provided for, which means that it is difficult for common people, who cannot rely on any kind of professional knowledge, to legislate. As regards the citizens' right to veto a parliamentary resolution, it should be noted that it is a joint action carried out in compliance with the President or with one-third of the members of the Parliament: without the preliminary action of the authorities, the popular veto to repeal a law cannot be triggered. A special and unique institutional feature that was recently given to Latvians is the right to recall the Parliament and to set new elections for it, however, such a right allows to take decisions on public governing bodies and not on substantive issues.

Despite the availability of several direct democratic tools, Latvia is equipped very poorly with procedural provisions. For all types of the referendum, there are restrictive rules that exclude certain issues from direct legislation. Additionally, a high number of signatures (10\% of the electorate) are required to be collected in a very short period to launch a citizen-initiated referendum. However, since January 2015, the collection time for the same amount of signatures lasts 12 months. Options for signature gathering are limited since the collection cannot be done in every public place. Furthermore, the restrictions and the framework are relatively complicated and not very citizen-friendly. 
The biggest hurdle is the approval quorum, which makes it very difficult to get valid referendum decisions (Kaufmann and Dane Waters 2004, 77).

Regarding the initiative procedure, there is an indirect initiative process, yet only to a certain degree. Indeed, it obliges the Latvian Parliament to debate all popular initiatives before they can be proposed to the people's decision. In its considerations, the Parliament generally rejects citizens' initiative and calls a referendum on it. The Parliament has also the possibility to directly adopt citizens' proposals without submitting them for a referendum. Through the Parliament's involvement in public legislation, a link is made between representative democracy and direct democracy because citizens and representatives come mutually closer. However, at that stage, there are no provisions in the Latvian system for counter-proposals or withdrawals that would lead to a compromise between the Parliament and the initiators.

Finally, as to the matter of turnout and approval quorums, Latvia does not perform very well either. To validate a popular vote in almost every kind of referendum, a different majority requirement is required. For a mandatory constitutional referendum and a citizens' constitutional referendum, indeed, no formal turnout requirement is requested, nevertheless, it is often registered a high turnout. More than half of all eligible voters are needed for such a referendum to be successful. Other approval quorums mostly consist of the number of the electors who participated in the previous parliamentary elections. The only positive aspect of such procedural criteria is that the outcome of a referendum is binding. Nevertheless, this provision alone did and does not actually enable the people to become a veto player within the decision-making process, nor does it particularly facilitate their implementation of direct democratic tools (Somer 2014, 170-171).

Particularly, concerning the referendum on constitutional amendments and popular initiatives rejected by Saeima, the quorum is certainly the most important element. In this field, it is important to remember that, after 1991, the average turnout in Latvia for national parliamentary elections was approximately $67 \%,{ }^{59}$ while the EU Parliament elections were characterized by a very low average turnout of $40 \%{ }^{60}$ Moreover, ten national referendums were held, yet only four reached the $50 \%$ threshold (on the independence of 1991, on the facilitated naturalization reform of 1998, on the EU accession of 2003, and on Russian as the second official language of 2012), while the only one did not need a quorum (the one on the parliamentary dissolution by presidential initiative of 2011). Contrarily there was an insufficient turnout for three optional veto referendum (on the abolition of the retirement system reform and on the abolition of amendments to the laws on the National Security Services) and two

\footnotetext{
59 General elections in Latvia were held in one round from the first vote of 1993 after the regained independence. The average turnout is 68.43\%: the biggest participation was registered in 1993's parliamentary elections with a turnout of $89.90 \%$, followed by an intense decrease in the next consultations from 1995 to 2018 with lesser participation of 54.56\%. Among all the votes made since the regained independence on, the turnout of the referendum on Latvia's accession to the EU was higher, i.e. with $73.12 \%$, while the referendum on popular initiative for Russian as second official language reached $71.13 \%$, both exceeded only by the referendum on independence with $87.56 \%$, although all permanent residents of Latvia, aged 18 and older, participated in the vote.

${ }^{60}$ The turnout of EU Parliament elections was characterized by a low average turnout of $39.70 \%$, with the minimum of $30.24 \%$ in the 2014 's vote and the maximum of $41.34 \%$ in the 2004 's vote.
} 
automatic referendum on rejected popular initiatives by Saeima (on the limited increase of public pensions and on the recall of the Parliament by people's initiative).

Thus, as regards the mandatory referendum on constitutional amendments and on popular initiatives rejected by Saeima, only initiatives with an enormous mobilizing power will have the chance to be adopted using the referendum. Better, only a referendum on a very populist theme was able to hit the target although there have been two referendums on the pensions in Latvia, which could be named as a "populist theme", yet both referendums did not meet the threshold. On the contrary for the one on the Russian as the second official language. Indeed, in Latvia as well as in every country with quorum rules, the opponents are always interested in campaigns which are aimed at talking their adherents out of participation with an obstructionist strategy (the so-called "sabotage of quorum"): it is much easier to hinder the success of a referendum with abstention (or invalid votes) than by means of positive argumentation to take validly part in the vote. Comparatively, in some national referendums of the EU states, it is not required to reach a quorum, but in fourteen countries there are different participation or/and approval quorum. ${ }^{61}$ This since that quorums assimilate voters who abstain to those who vote "no".

Summing up, the introduction of direct democracy tools in the Latvian constitutional law allowed the people to play an active role in political matters, so it represents a positive step forward in the process of acknowledging the status of the citizens. In conclusion, it can be pointed out that Latvia has not risen to the challenge of striking a balance between representative and direct democracy yet. Indeed, to reach this goal, it is not enough to provide citizens with different direct democratic mechanisms. To this end, posing obstacles and high hurdles doesn't help as well, while on the contrary promotion of a strong civil society and more active people's participation in direct legislation should be encouraged (Somer 2014, 180).

\section{References}

Aguiar-Conraria, L., and Magalhães, P.C., 2009. Referendum Design, Quorum Rules and Turnout. Public Choice [online], 144(1-2) [first online: 19 September 2009]. Available from: https://doi.org/10.1007/s11127-009-9504-1 [Accessed 1 June 2020].

Albi, A., 2003. EU Accession Referendums in the Baltic States. Tilburg Foreign Law Review, no 11, 666-667.

Albi, A., 2005. EU Enlargement and the Constitutions of Central and Eastern Europe. Cambridge University Press, 94-98.

Altman, D., 2014. Direct Democracy Worldwide. Cambridge University Press.

Altman, D., 2019. Citizenship and Contemporary Direct Democracy. Cambridge University Press.

Auer, A., 1995. La justice constitutionnelle et la démocratie référendaire - Rapport de synthèse. Science et technique de la démocratie [online], nº 14-Justice

\footnotetext{
61 Participation quorum in Bulgaria, Hungary, Italy, Malta, Netherlands, Poland, Portugal, Romania, Slovakia, and Slovenia; approval quorum in Denmark and Ireland; both quorum in Latvia (constitutional referendum) and Lithuania. See Aguiar-Conraria and Magalhães 2009.
} 
constitutionnelle et démocratie référendaire, 149. European Commission for Democracy through Law, Strasbourg, 23-24 June. Available from:

https://www.venice.coe.int/webforms/documents/default.aspx?pdffile=CDLSTD(1995)014-f [Accessed 1 June 2020].

Auer, A., and Bützer, M., 2001. General conclusion. In: A. Auer and M. Bützer, eds., Direct Democracy: the Eastern and Central European Experience. Farnham: Ashgate, 353.

Avbelj, M., and Komárek, J., 2012. Constitutional Pluralism in the European Union and Beyond. Oxford: Hart.

Bagni, S., 2017. Il popolo legislatore. Bolonia University Press.

Baldin, S., 2008. Il referendum revocatorio del Presidente della Repubblica romena: circolazione e adattamento di un singolare istituto. Diritto Pubblico Comparato ed Europeo, 66, 72-74.

Baldin, S., 2012. I referendum arbitrali fra teoria e prassi applicative. Federalismi.it [online], $\mathrm{n}^{\mathrm{o}}$ 19. Available from:

https://federalismi.it/ApplOpenFilePDF.cfm?artid=20943\&dpath=document\&dfil e $=08102012181448$.pdf\&content $=\mathrm{I} \% 2 \mathrm{Breferendum} \% 2 \mathrm{Barbitrali} \% 2 \mathrm{Bfra} \% 2 \mathrm{Bteoria} \%$ 2Be $\% 2$ Bprassi $\% 2$ Bapplicative $\% 2 \mathrm{~B} \% 2 \mathrm{D} \% 2 \mathrm{Bstato} \% 2 \mathrm{~B} \% 2 \mathrm{D} \% 2 \mathrm{Bdottrina} \% 2 \mathrm{~B} \% 2 \mathrm{D} \% 2$ B [Accessed 1 June 2020].

Balodis, R., Kārkliṇa, A., and Danovskis, E., 2013. The Development of Constitutional and Administrative Law in Latvia after the Restoration of Independence. Law [online], no 5, 44-119. Available from:

https://www.journaloftheuniversityoflatvialaw.lu.lv/fileadmin/user upload/lu p ortal/projekti/journaloftheuniversityoflatvialaw/No5/3.Ringolds Balodis Annija Karklina Edvins Danovskis.pdf [Accessed 1 June 2020].

Bleiere, D., et al., eds., 2006. History of Latvia: The 20th Century. Riga: Jumava.

Bosioc, D., 2013. Romania: la sospensione del Presidente Traian Băsescu e il referendum revocatorio del 29 luglio 2012. Diritto Pubblico Comparato ed Europeo, no 1, 271-288.

Burdeau, G., 1950. Il regime parlamentare nelle Costituzioni europee del dopoguerra. Milan: Comunità, 262-264.

Butler, D., and Ranney, A., 1994. Referendums around the World: The Growing Use of Direct Democracy. London: Palgrave Macmillan.

Cazejus, A., 1925. La Constitution de la Lettonie. Toulouse: Faculté de Droit.

Ciammariconi, A., and Di Gregorio, A., 2005. Il referendum nei nuovi Stati membri dell'Unione europea. Diritto pubblico comparato ed europeo, $\mathrm{n}^{\circ}$ 3, 1406-1426.

Constitutional Court of the Republic of Moldova, 2011. Raport cu privire la exercitarea jurisdicţiei constituţionale în anul 2010, prezentat în baza art.80 din Codul jurisdicţiei constituţionale [Report on the Exercise of Constitutional Jurisdiction in 2010, presented on the basis of Article 80 of the Code of constitutional jurisdiction] (online). Chisinau: Constitutional Court of the Republic of Moldova. Available 
from:

https://constcourt.md/public/files/file/Actele\%20Curtii/acte\%202011/h_01.pdf

[Accessed 1 June 2020].

Dau, F.R., 2011. Referendum sullo scioglimento del Saeima. NAD, Osservatorio su nuovi autoritarismi e democrazie [online], 8 September. Available from: https://nad.unimi.it/lettonia-referendum-sullo-scioglimento-del-saeima/ [Accessed 1 June 2020].

De Francesco, G., 1933. La posizione giuridica del capo dello Stato nelle vecchie e nelle nuove Costituzioni. In: Cedam, ed., Studi in onore di Federico Cammeo. Padua: Cedam, 335-336.

De Pretis, A., 2004. Da “We the people" a “Hasta la vista, Davis!": origini, evoluzioni e profili di costituzionalità del recall negli ordinamenti degli Stati Uniti. Diritto pubblico comparato ed europeo, $\mathrm{n}^{\mathrm{o}}$ 4, 1793-1836.

De Vergottini, G., 2013. Diritto costituzionale comparato. Padua: Cedam.

Denquin, J.M., 1976. Référendum et plébiscite: essai de théorie générale. Paris: LGDJ.

Duvold, K., 2010. Making Sense of Baltic Democracy: Estonia, Latvia and Lithuania between Soviet Union and the European Union. Balti/Chisinau/Riga/Beau-Bassin: Lambert Academic.

Endziņš, A., 2000. European Integration and Constitutional Law: the Situation in Latvia. UniDemi Seminar European Integration and Constitutional Law. Cyprus, 29-30 September.

Fara, V., 2012. Revocatoria de mandato: origini e diffusione di un particolare istituto di democrazia diretta in America Latina. Diritto pubblico comparato ed europeo, $\mathrm{n}^{\mathrm{o}} 3$, 962-977.

Fekete, B., 2018. The Limits of Sovereignty Pooling: Lessons from Europe. In: M. Belov, ed., Global Constitutionalism and Its Challenges to Westphalian Constitutional Law. Oxford: Hart, 153.

Fossedal, G., 2002. Direct Democracy in Switzerland. Piscataway: Transaction.

Frison-Roche, F., 2005. Le "modèle semi-présidentiel" comme instrument de la transition en Europe post-communiste. Brussels: Bruylant.

Frosini, T.E., 2008. Forme di governo e partecipazione popolare. Milan: Giappichelli.

Gallagher, M., and Uleri, P.V., eds., 1996. The Referendum Experience in Europe. London: Palgrave Macmillan.

García, E., Palici Di Suni, E., and Rogoff, M., eds., 2018. Gli istituti di democrazia diretta nel diritto comparator. Padua: Cedam.

Habracevica, S., 2001. Working Group's Draft Amendments. Riga: The Sovereignty of Latvia and Membership of the EU Conference, 23 November.

Hamon, F., 2012. Le référendum: étude comparative. $2^{\text {nd }}$ ed. Paris: LGDJ-Lextenso.

Haungs, P., 1968. Reichspräsident und parlamentarische Kabinettsregierung. Opladen: Westdeutscher. 
Held, D., 2006. Models of Democracies. Cambridge: Polity Press.

Helstein, M.C., 1930. La Constitution de la République de Lettonie. Paris: Recueil Sirey.

Jarinovska, K., 2013. Popular Initiatives as Means of Altering the Core of the Republic of Latvia. Juridica International [online], no 20, 152-159. Available from: https://www.juridicainternational.eu/index.php?id=15331 [Accessed 1 June 2020].

Jasiewicz, K., 2004. Knocking on Europe's Door. Voting Behaviour in the EU Accession Referendum in Poland. Problems of Post-Communism [online], 51(5), 34-44.

Available from: https://doi.org/10.1080/10758216.2004.11052182 [Accessed 1 June 2020].

Kārklina, A., 2013. Dissolution of Parliament in Latvia: Legal Regulation and Practice. Jurisprudencija [online], 20(3), 1213-1229. Available from: https://doi.org/10.13165/JUR-13-20-3-18 [Accessed 1 June 2020].

Kārklina, A., 2014. Rights of the Entirety of Citizens in Legislative Process in Latvia. Curentul Juridic-Juridical Current [online], vol. 57, 62. Available from: https://ideas.repec.org/a/pmu/cjurid/v57y2014p60-72.html [Accessed 1 June 2020].

Kārkliṇa, A., 2017. Requirements to be Set for Voters' Legislative Initiatives in the Republic of Latvia: Legal Regulation, Practice, and Recent Findings of Judicature. Law [online], no 10, 152-174. Available from: https://doi.org/10.22364/jull.10.11 [Accessed 1 June 2020].

Kaufmann, B., and Dane Waters, M., eds., 2004. Direct Democracy in Europe: a Comprehensive Reference Guide to the Initiative and Referendum Process in Europe. Durham: Carolina Academic Press.

Kaufmann, B., Büchi, R., and Braun, N., eds., 2010. Guidebook to Direct Democracy in Switzerland and Beyond. The Initiative \& Referendum Institute Europe.

King, R.F., and Sum, P.E., eds., 2011. Romania under Băsescu: Aspirations, Achievements, and Frustrations during his First Presidential Term. Lanham: Lexington Books.

Kobach, K.W., 1993. The Referendum: Direct Democracy in Switzerland. London: Dartmouth.

Krapivnitskaya, E., 2016. Moldavia - Elezioni presidenziali. Federalismi.it [online], nำ2 (News dal mondo). Available from:

https://federalismi.it/ApplOpenFilePDF.cfm?artid=32755\&dpath=document\&dfil e=16112016191821.pdf\&content=Moldavia \%2B\%2D\%2BElezioni $\% 2 B$ presidenziali \%2B $\% 2 \mathrm{D} \% 2 \mathrm{Bnews} \% 2 \mathrm{~B} \% 2 \mathrm{D} \% 2 \mathrm{Bnews} \% 2 \mathrm{Bdal} \% 2 \mathrm{Bmondo} \% 2 \mathrm{~B} \% 2 \mathrm{D} \% 2 \mathrm{~B}$ [Accessed 1 June 2020].

Krūma, K., 2014. EU Citizenship, Nationality and Migrant Status: An Ongoing Challenge. Leiden: Martinus Nijhoff.

Lauvaux, P., 1983. La dissolution des assemblées parlementaires. Paris: Economica.

Lieven, A., 1993. The Baltic Revolution. Estonia, Latvia, Lithuania and the Path to Independence. New Haven: Yale University Press. 
Markesinis, B., 1972. The Theory and Practice of Dissolution of Parliament. A Comparative Study with Special Reference to the United Kingdom and Greek Experience. Cambridge University Press.

McGrane, S., 2013. Online, Latvians' Ideas Can Bloom Into Law. The New York Times [online], 10 April. Available from: https://www.nytimes.com/2013/04/10/world/europe/a-web-site-where-latviansideas-can-become-law.html [Accessed 1 June 2020].

Mendez, F., Mendez, M., and Triga, V., 2014. Referendums and the European Union. A Comparative Inquiry. Cambridge University Press.

Mikkel, E., and Fridham, G., 2007. Clinching the "Return to Europe": The Referendums on EU Accession in Estonia and Latvia. West European Politics [online], 27(4), 716748. Available from: https://doi.org/10.1080/0140238042000249958 [Accessed 1 June 2020].

Morel, L., and Qvortrup, M., eds., 2018. The Routledge Handbook to Referendums and Direct Democracy. Abingdon: Routledge.

Nutt, M., 2005. Restoration of Independence and the Fourth Constitution (1992-...). Estonica. Encyclopedia about Estonia [online]. Available from:

https://www.estonica.org/en/The state order of Estonia in its historical devel opment/Restoration of independence and the fourth Constitution 1992 \%E2\%80\%A6 / [Accessed 1 June 2020].

Pleps, J., 2003. Kādā Veidā Var Atlaist Saeimu. Jurista Vārds [online], no 46. Available from: https://juristavards.lv/doc/82356-kada-veida-var-atlaist-saeimu/ [Accessed 1 June 2020].

Pollicino, O., 2018. The President of the Republic. In: G.F. Ferrari, ed., Introduction to Italian Public Law. Milan: Giuffrè Francis Lefebvre, 148.

Pollock, J.K., 1923. The Constitution of Latvia. American Political Science Review [online], 17(3), 447. Available from: https://doi.org/10.2307/1944058 [Accessed 1 June 2020].

Pryce, P., 2012. The 2011 Parliamentary Election in Latvia. Electoral Studies [online], 31(3). Available from: https://dx.doi.org/10.1016/j.electstud.2012.05.006 [Accessed 1 June 2020].

Qvortrup, M., 2014. Referendums around the World: The Continued Growth of Direct Democracy. London: Palgrave Macmillan.

Qvortrup, M., 2017. Direct Democracy: A Comparative Study of the Theory and Practice of Government by the People. Manchester University Press.

Ratto Trabucco, F., 2017. The Evolution of Referendum Experience in Hungary. The Journal of Comparative Law [online], 12(1). Available from:

https://www.academia.edu/34030542/The Evolution of Referendum Experience in Hungary [Accessed 1 June 2020].

Rodina, A., 2011. Constitutional Law 2010. Republic of Latvia. European Review of Public Law [online], 23(4), 1306-1312. Available from: 
https://eplopublications.eu/publication/digital-edition/constitutional-law-droitconstitutionnel-2010-republic-latvia-republique [Accessed 1 June 2020].

Rodina, A., 2012. Constitutional Law 2011. Republic of Latvia. European Review of Public Law [online], 24(4), 1525-1535. Available from:

https://eplopublications.eu/publication/digital-edition/constitutional-law-droitconstitutionnel-2011-republic-latvia-republique [Accessed 1 June 2020].

Roznai, Y., 2019. Unconstitutional Constitutional Amendments: The Limits of Amendment Powers. Oxford University Press.

Ruth-Lovell, S.P., Welp, Y., and Whitehead, L.A., 2017. Let the People Rule? Direct Democracy in the Twenty-first Century. London: ECPR Press.

Ruus, J., 2011. Democratic Participation at the Local Level in Post-communist States: Estonia, Latvia, Lithuania. In: T. Schiller, ed., Local Direct Democracy in Europe. Heidelberg: Springer VS, 272.

Schiller, T., ed., 2011. Local Direct Democracy in Europe. Heidelberg: Springer VS.

Shen, Y., 2009. The Anomaly of the Weimar Republic's Semi-Presidential Constitution. Journal of Politics and Law [online], 2(3). Available from: https://doi.org/10.5539/jpl.v2n3p35 [Accessed 1 June 2020].

Sikk, A., 2005. How Unstable? Volatility and the Genuinely New Parties in Eastern Europe. European Journal of Political Research [online], 44(3), 391-412. Available from: https://doi.org/10.1111/j.1475-6765.2005.00232.x [Accessed 1 June 2020].

Somer, E., 2014. Direct Democracy in the Baltic States. Institutions, Procedures and Practice in Estonia, Latvia and Lithuania. Bern: Peter Lang.

Suksi, M., 1993. Bringing in the People: A Comparison of Constitutional Forms and Practices of the Referendum. Leiden: Martinus Nijhoff.

Tănăsescu, E.S., 2008. The President of Romania, or: The Slippery Slope of a Political System. European Constitutional Law Review [online], 4(1). Available from: https://doi.org/10.1017/S1574019608000643 [Accessed 1 June 2020].

Taube, C., 2001. Constitutionalism in Estonia, Latvia and Lithuania. A Study in Comparative Constitutional Law. Uppsala: Iustus Forlag.

Thorarensen, B., 2015. Constitutional Consequences of the Economic Crisis in Iceland. Diritto pubblico [online], nำ 3, 723-748. Available from: https://doi.org/10.1438/82174 [Accessed 1 June 2020].

Uleri, V., 2003. Referendum e democrazia: Una prospettiva comparata. Bologna: Il Mulino.

Vilka, I., Pukis, M., and Vanags, E., eds., 2006. Indicators of Local Democracy in Latvia. Department of Baltic Studies of Tartu University.

Volpi, M., 1983. Lo scioglimento anticipato del parlamento e la classificazione dei regimi contemporanei. Santarcangelo di Romagna: Maggioli.

Welp, J., 2018. Recall Referendum around the World: Origins, Institutional Designs and Current Debates. In: L. Morel and M. Qvortrup, eds., The Routledge Handbook to Referendums and Direct Democracy. Abingdon: Routledge, 451-463. 
Wilk, J., 2013. Kilka uwag do rozszerzenia zakresu przedmiotowego referendum lokalnego. Nowe Zeszyty Samorzadowe, no 3, 11-26.

Case law

Judgment of the Latvian Constitutional Court of 12 February 2014, case n 2013-05-01.

Judgment of the Latvian Constitutional Court of 19 December 2012, case no 2012-03-01.

Judgment of the Latvian Constitutional Court of 19 May 2009, case n²008-40-01.

Judgment of the Latvian Constitutional Court of 29 November 2007, case no 2007-100102.

Judgment of the Latvian Constitutional Court of 7 April 2009, case no 2008-35-01.

Judgment of the Moldavian Constitutional Court, March 4, 2016, n. 7, On constitutional review of given provisions of Law no. 1115-XIV of July 5, 2000, amending the Constitution of the Republic of Moldova (presidential election procedure) (Complaint $n^{\circ}$ 48b/2015) [online]. Available from:

https://www.constcourt.md/public/ccdoc/hotariri/en-Judgment-72016-in-Englishfinal86c86.pdf [Accessed 1 June 2020].

Legal sources

Code of Good Practice on Referendums, para. III.7, by Council for Democratic Elections at its XIX meeting of December 16, 2006, and Venice Commission at its LXX plenary session of March 16-17, 2007 (CDL-AD(2007)008rev-cor) [online]. Strasbourg: European Commission for Democracy through Law (Venice Commission), 25 October 2018. Available from:

https://www.venice.coe.int/webforms/documents/default.aspx?pdffile=CDLAD(2007)008rev-cor-e [Accessed 1 June 2020].

Par Saeimas atlaišanas ierosināšanu [online]. Latvijas Valsts Prezidenta Rīkojums no 2. 28 May 2011. Available from: https://www.likumi.lv/doc.php?id=230900 [Accessed 1 June 2020].

Riigikogu Rules of Procedure and Internal Rules Act (RT I 2007, 44, 316 - entry into force 14.07.2007). Riigi Teataja [online]. Available from:

https://www.riigiteataja.ee/en/eli/ee/Riigikogu/act/512032015002/consolide/curren t [Accessed 1 June 2020].

Valsts prezidenta Konstitucionālo tiesību komisija [Constitutional Law Commission of the State President], 2008. Riga: Latvijas Vēstnesis. 